\title{
Sedimentation, depositional environments, and hydrocarbon potential of the Maastrichtian-Paleocene Araromi Formation, eastern Dahomey (Benin) Basin, southwestern Nigeria
}

\author{
Oladotun Afolabi Oluwajana ${ }^{1}$ (1) - Abraham Olatunji Opatola ${ }^{2}$. Olajide Jonathan Adamolekun ${ }^{3}$. \\ Otobong Sunday Ndukwe ${ }^{4}$. Gabriel Toluwalope Olawuyi ${ }^{5}$. Collins Uche Ofiwe ${ }^{6}$. Taiwo Ayodele Bolaji ${ }^{4}$. \\ Bamidele Adeniyi Adebambo ${ }^{7}$. Oladipo Omoniyi Oluwajana ${ }^{8}$
}

Received: 25 January 2021 / Accepted: 12 August 2021 / Published online: 26 August 2021

(c) The Author(s) 2021

\begin{abstract}
The Cretaceous sediments in southwestern Nigeria are host to one of the largest bitumen deposits in the world. In the current paper, an integrated study on sedimentology, palynology, and applied petroleum geochemistry of the Maastrichtian-Paleocene Araromi Formation was used to determine the depositional environments and hydrocarbon potentials of the formation on the eastern Dahomey Basin. Four sedimentary lithofacies were identified from core samples, namely, lower limestone $\left(\mathrm{F}_{1}\right)$; medium to coarse-grained sandstone $\left(\mathrm{F}_{2}\right)$; lower loosely consolidated sandstone $\left(\mathrm{F}_{3}\right)$; and shale and siltstone $\left(\mathrm{F}_{4}\right)$. Sedimentation in the eastern Dahomey Basin occurred mainly in fluvial and shallow-marine (shelf) environments. The palynological assemblages of the Araromi Formation reflect deposition in coastal through brackish water to shallow shelf environment with periods of localized wind-induced storms. The shale and siltstone samples of the Araromi Formation are characterized by total organic carbon (TOC) values of up to $2.50 \mathrm{wt} \%$ and $\mathrm{S}_{2}$ (hydrocarbon-generating potential) values ranging from 0.26 to $0.70 \mathrm{mgHC} / \mathrm{g}$ rock, indicating poor source rocks. Shales show poor quality and thermally immature organic matter at shallow depth and could neither have generated liquid hydrocarbon nor contributed to the heavy oil occurrence on the bitumen and tar-sand belt of eastern Dahomey (Benin) Basin.
\end{abstract}

Keywords Depositional environments $\cdot$ Lithofacies $\cdot$ Petroleum potentials $\cdot$ Dahomey (Benin) Basin $\cdot$ MaastrichtianPaleocene

\section{Introduction}

The eastern part of the Dahomey Basin in Nigeria hosts the second-largest bitumen resources in the world, with an estimated proven reserve of about 42.47 billion tonnes of

Oladotun Afolabi Oluwajana

oladotun.oluwajana@aaua.edu.ng;

afolabi.oladotun@gmail.com

1 Department of Earth Sciences, Adekunle Ajasin University, Akungba-Akoko, Nigeria

2 Department of Geosciences, University of Lagos, Lagos, Nigeria

3 Department of Structural Geology and Tectonics, Institute of Applied Geosciences, Karlsruhe Institute of Technology, Adenauerring 20a, 76131 Karlsruhe, Germany

4 Department of Geology, Federal University Oye-Ekiti, Oye-Ekiti, Nigeria bitumen and oil sand that is yet to be explored for economic purposes (Famakinwa et al. 2010; Olabemiwo et al. 2016). Oil seeps in the eastern Dahomey (Benin) Basin were a source of attraction to early explorationists, between 1907 and 1960 . The results of these early exploration campaigns

5 Department of Marine Geosciences, Leon H. Charney School of Marine Sciences, University of Haifa, Haifa, Israel

6 Centre of Excellence in Nanotechnology and Advanced Materials (NASENI CoEx-NA), National Agency for Science and Engineering Infrastructure, Akure, Nigeria

7 Department of Geology, Obafemi Awolowo University, Ile-Ife, Nigeria

8 Department of Environmental Sciences, Cyprus International University, Nicosia, Cyprus 
confirmed the presence of heavy biodegraded oils in shallow wells and boreholes in the basin (Coker et al. 2002). Bitumen and oil sands have been found in Cretaceous outcrops, and flows/shows in drilled and cored wells (Nwachukwu and Ekweozor, 1989; Macgregor et al. 2003; MSMD, 2006). Oil indications from outcrop sections and boreholes in the eastern Dahomey (Benin) Basin are suggestive of potential economic discoveries, but the overall petroleum geology of the region has not been fully understood. The source of the bitumen in the basin is unresolved. The current study considers depositional environments and hydrocarbon potentials of the Maastrichtian-Paleocene Araromi Formation on the eastern Dahomey (Benin) Basin of southwestern Nigeria.

Omatsola and Adegoke (1981) and Okosun (1990) reviewed the Cretaceous sedimentary sequence of the eastern Dahomey Basin. Adegoke et al. (1977) and Oluwajana et al. (2021) dated the bituminous shales of the Araromi Formation using foraminiferal assemblages. Recent works on the geochemistry of the Maastrichtian-Paleocene strata include Akande et al. (2018), Famakinwa et al. (2010), and Ogala et al. (2019). Adekeye et al. (2019) suggested that the shale facies of the Araromi Formation have low hydrocarbon potential. Famakinwa et al. (2010) reported that the organic matter of the Araromi Formation in the eastern Dahomey (Benin) Basin is of mixed terrestrial and marine origin. None of these earlier studies integrated sedimentological, palynological and organic geochemical data in their attempts to determine the depositional environments and hydrocarbon potential of the formation. This current paper therefore presents data and interpretations from core logging, palynological as well as total organic carbon (TOC)/ programmed pyrolysis (Rock-Eval) results of shale samples recovered from four exploration boreholes (Fig. 1), with a view to providing an integrated approach to the understanding of the hydrocarbon potential of the Araromi Formation in the eastern Dahomey (Benin) Basin.

\section{Geologic framework}

The Dahomey (Benin) Basin constitutes part of the West African peri-cratonic system (margin sag) basin (Klemme 1975; Akinmosin et al. 2012), which developed following the rifting associated with the opening of the Gulf of Guinea, in the Late Jurassic to Early Cretaceous (Burke et al. 1971; Whiteman 1982; Akinmosin et al. 2012). The crustal separation, typically preceded by crustal thinning, was accompanied by an extended period of thermally induced basin subsidence through the mid-Late Cretaceous to PaleogeneNeogene times as the South American and the African plates entered a drift phase to accommodate the emerging Atlantic Ocean (Akinmosin et al. 2012).
The basin stretches along the coast of Nigeria, Benin Republic, Togo, and Ghana, on the margin of the Gulf of Guinea (Olabode 2006). It is separated from the Niger Delta on the eastern section by the Benin Hinge Line and Okitipupa Ridge and marks the continental extension of the chain fracture zone (Olabode 2006). It is bounded on the west by the Ghana Ridge and has been interpreted as the Romanche fracture zone (Burke et al. 1971; Whiteman 1982). The onshore part of the basin covers a broad arcshaped profile of about $600 \mathrm{~km}^{2}$ in extent (Olabode and Adekoya 2007). The basin narrows to about $50 \mathrm{~km}$ on the eastern side, where the basement assumes a convex upwards outline with concomitant thinning of sediments (Olabode 2006).

The Cretaceous stratigraphy consists of the Abeokuta Group, sub-divided into the Abeokuta and Araromi formations (Fig. 2), (Okosun 1990). The basal sequence is a fluviatile sandstone of the Lower Cretaceous to Maastrichtian Abeokuta Formation (Okosun 1990; Petters 1991), which unconformably overlies the crystalline basement complex (Kaki et al. 2013). The Maastrichtian to Paleocene Araromi Formation comprises fine-grained basal sand overlain by shale and siltstones with thin intercalations of marl and shelly limestone (Omatsola and Adegoke 1981; Enu and Adegoke 1988; Okosun 1990). Araromi shale is divided into the upper Paleocene Member and the lower Maastrichtian Member (Petters 1991; Kaki et al. 2013). The PaleogeneNeogene sediments comprise the Paleocene Imo Shale/ Ewekoro Formation, Eocene Oshosun/Akinbo Formation, Oligocene-Miocene Ilaro Formation, and Miocene-Quaternary Benin Formation (Fig. 2), (Olabode 2006). The Imo Shale is composed of grey, dark grey, and black, laminated and calcareous shale with occasional white to brown sands (Okosun and Alkali 2012). Ewekoro Formation is made up of fossiliferous well-bedded limestone and associated with the shallow-marine environment, while Akinbo and Oshosun Formations are made up of flaggy grey and black shales (Elueze and Nton 2004; Olabode and Adekoya 2007). Glauconitic rock bands and phosphatic beds define the boundary between Ewekoro and Akinbo Formations (Enu and Adegoke 1988). Ilaro and Benin Formations comprise mainly cross-bedded and poorly sorted sandstones with estuarine to continental attributes (Kogbe 1974; Nton et al. 2006).

\section{Materials and methods}

The four exploration boreholes $(\mathrm{OH}-1, \mathrm{AK}-5, \mathrm{AI}-2$, and AY-8) provide a well-preserved record of the Araromi Formation. The cores from the boreholes were carefully logged and analyzed for sedimentological, palynological, and organic geochemical characteristics. The Maastrichtian-Paleocene shale and limestone samples were collected 

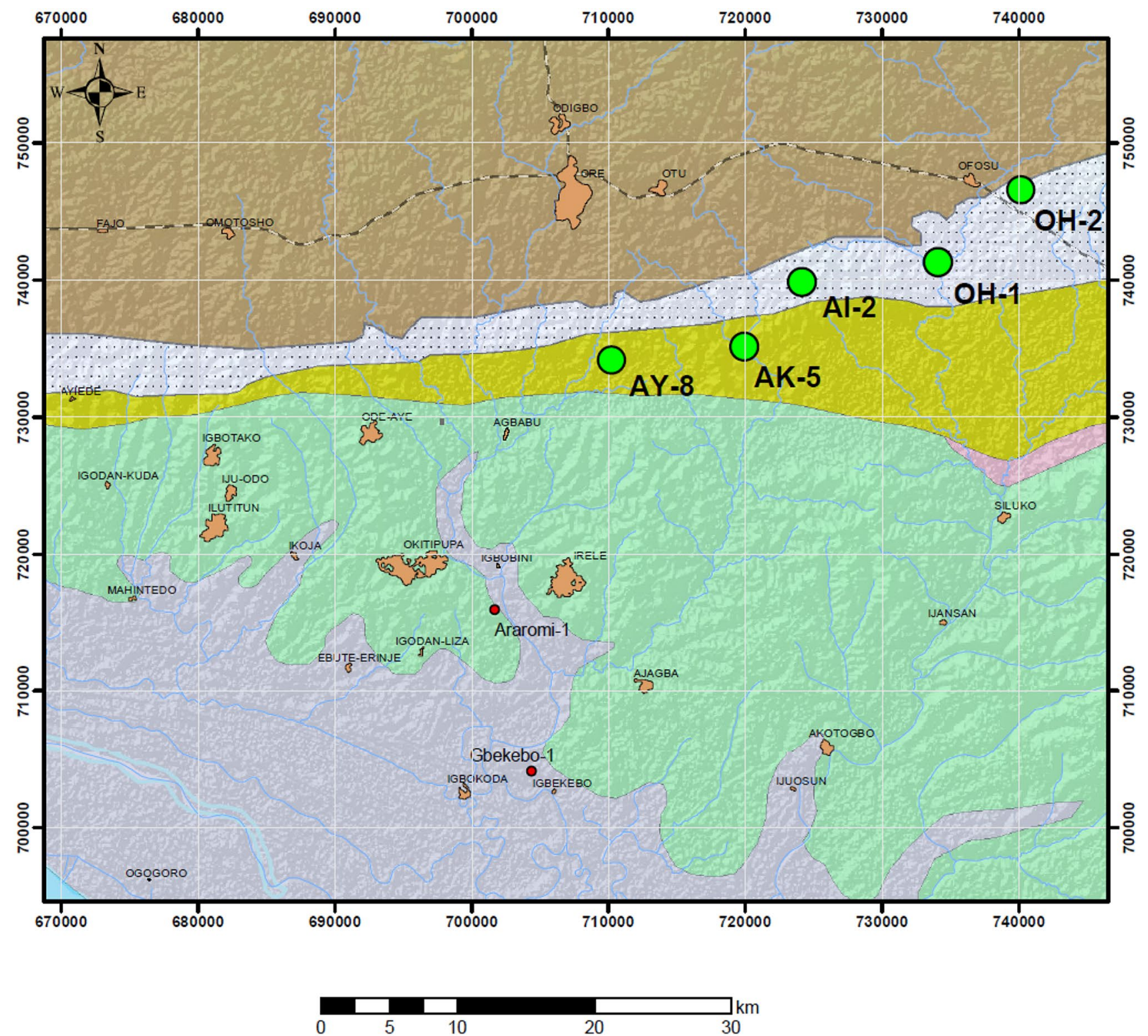

\section{Leqend}
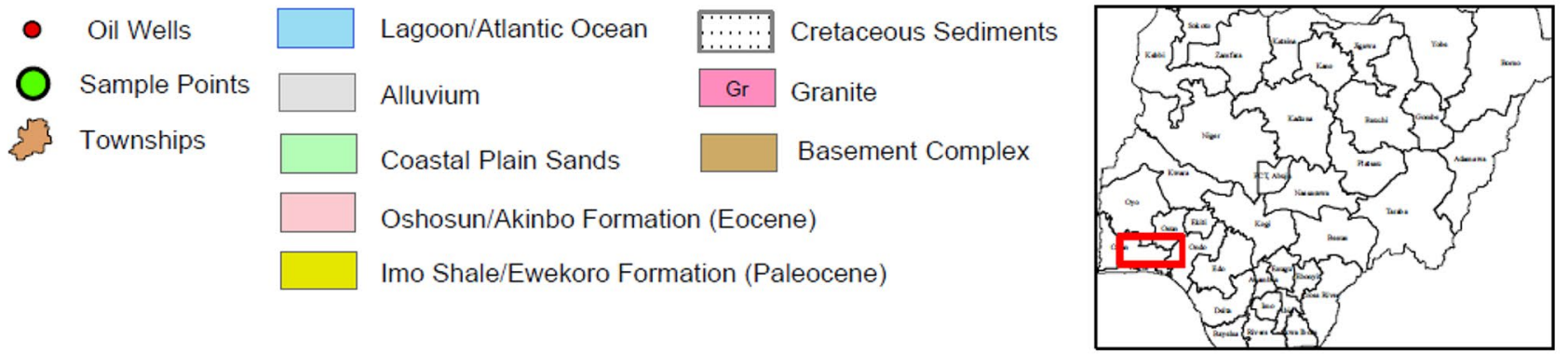

Fig. 1 The study area in simplified regional geographical/geological map showing outcrop and borehole locations (modified from Murat 1969; Oluwajana et al. 2020). Also highlighted on the map is the
Cretaceous to Quaternary sediments of the eastern Dahomey Basin. OH-1, AY-8, AK-5, and AI-2 are the studied boreholes 


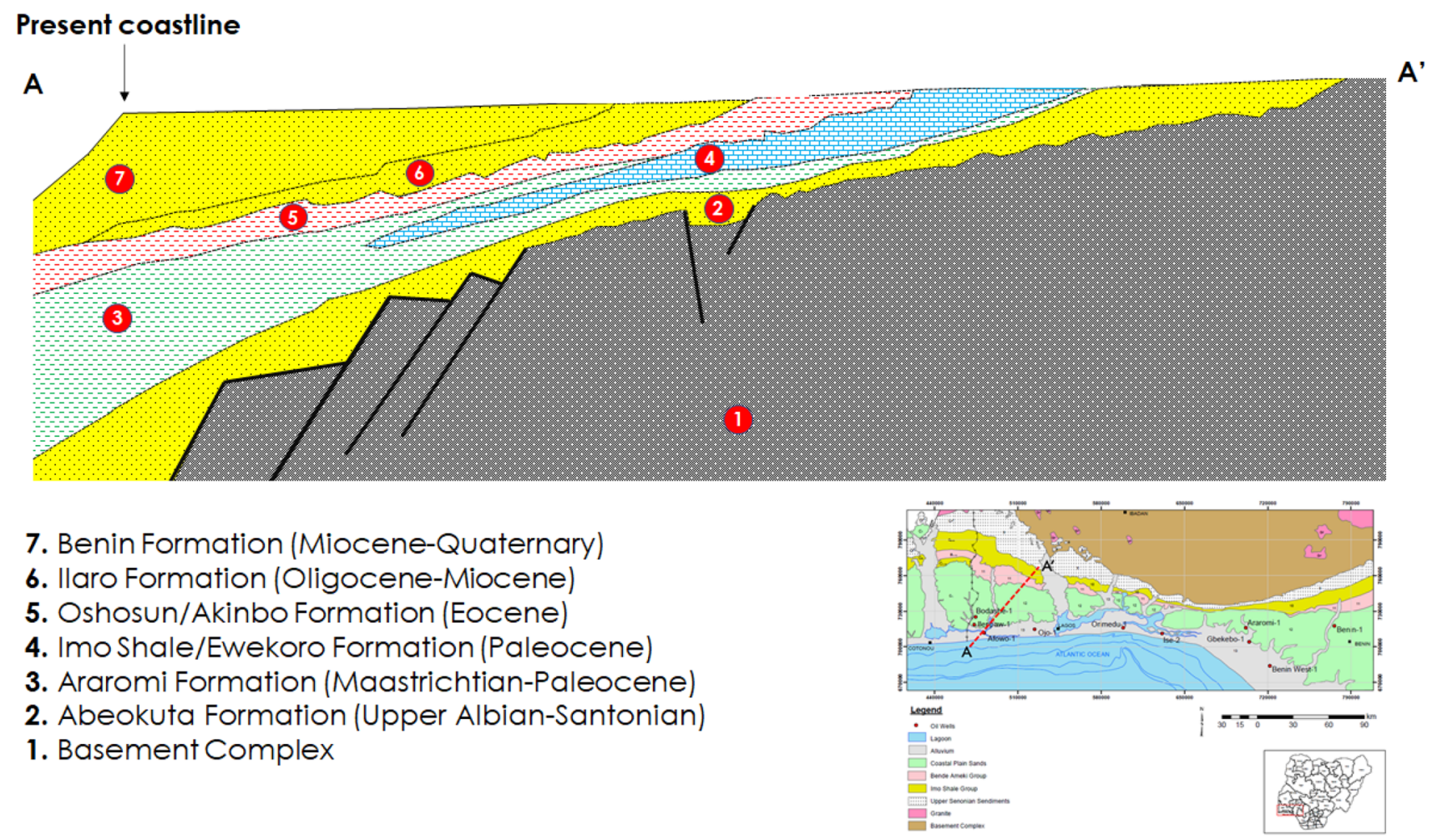

Fig. 2 Representative northeast-southwest stratigraphic sketch section across part of Eastern Dahomey (Benin) Basin. (Modified after Petters, 1982; Ajayi 1995). Inset. Location of the cross-section (modified after Murat 1969; Ehinola and Oluwajana 2016)

\section{Lithologies}

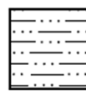

Siltstone

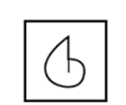

Shells

Base Boundaries

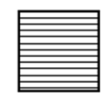

Shale

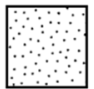

Sandstone

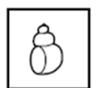

Gastropods

s
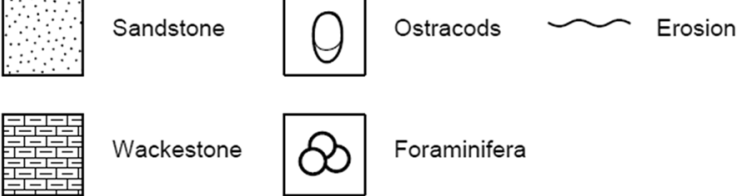

Wackestone

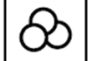

Foraminifera

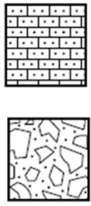

Packstone

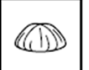

Echinoids

Overburden

Fig. 3 Key to symbols and abbreviations used in the measured borehole (core) sections (Figs. 4-7)

from the subsurface core section ((Figs. 4-8), see Fig. 1 for locations).
Sedimentological analysis of the cores from the boreholes was based on lithology, bed thickness, texture (grain size, shape, roundness, and sorting), and sedimentary structures. The representative shale samples were obtained for palynology and geochemical analyses. Fifteen shale samples from the exploration boreholes were prepared for palynological investigations using standard extraction techniques involving $\mathrm{HCl}$, and $\mathrm{HF}$ treatments, wet sieving, and mounting on glass slides using glycerine jelly. Slides were studied under the microscope and abundance of the palynomorphs were recorded using a light transmitted Olympus CX41 microscope.

Total organic carbon content, kerogen type, and thermal maturity were obtained from 40 to $50 \mathrm{mg}$ of dried powdered samples using a Rock-Eval II/TOC pyrolysis. Rock-Eval measures free hydrocarbons, kerogen-bound hydrocarbons, and the organic carbon content of a rock using pyrolysis (Peters 1986; Meilijson et al. 2020). The quantity of organic carbon in ten shale samples was determined using LECO carbon analyzer. Thermal maturity analyses of four shale samples were determined using a Rock-Eval II programmed pyrolysis. 


\section{Results}

\section{Sedimentology}

The sedimentary successions comprise siliciclastics and limestone. Four facies were identified, which consist of limestone $\left(\mathrm{F}_{1}\right)$, medium to coarse-grained sandstone $\left(\mathrm{F}_{2}\right)$, loosely consolidated sandstone $\left(\mathrm{F}_{3}\right)$, and shale and siltstone $\left(\mathrm{F}_{4}\right)$.

\section{Lithofacies $\left(F_{1}\right)$ : Basal Limestone}

\section{Description}

The limestone lithofacies is light grey and hard, with fossiliferous mudstone, wackestone, and packstone microfacies. This lithofacies was intercepted in three (3) boreholes, namely, AI-2, AK-5, and AY-8 (Figs. 5-7). The matrix is chiefly micritic (Oluwajana et al. 2020).

\section{Interpretation}

The wackestone and packstone textures indicate deposition in the proximal part of a subtidal lagoon (Lasemi et al. 2008). Carbonate lagoons are generally sites of wackestone and packstone deposition (Nichols 2009).

\section{Lithofacies $\left(F_{2}\right)$ : Medium- to coarse-grained sandstone}

\section{Description}

The 14-m thick ferruginized sandstone lithofacies in borehole $\mathrm{OH}-1$ is light yellowish to brown, medium- to coarsegrained sandstone, with poor to moderate sorting (Fig. 4). No obvious cross-stratification was observed. At certain intervals, siderite-cemented sandstone was noticed. Sparse bioturbation was observed in the sandstone lithofacies. Three-metre-thick siltstone bed was also observed interbedded with sandstone. The siltstone bed is laminated and sharp based.
Fig. 4 Stratigraphic log showing the identified lithofacies of the Maastrichtian-Paleocene Araromi Formation in $\mathrm{OH}-1$ borehole (see Fig. 1 for location, and Fig. 3 for symbols and abbreviations)

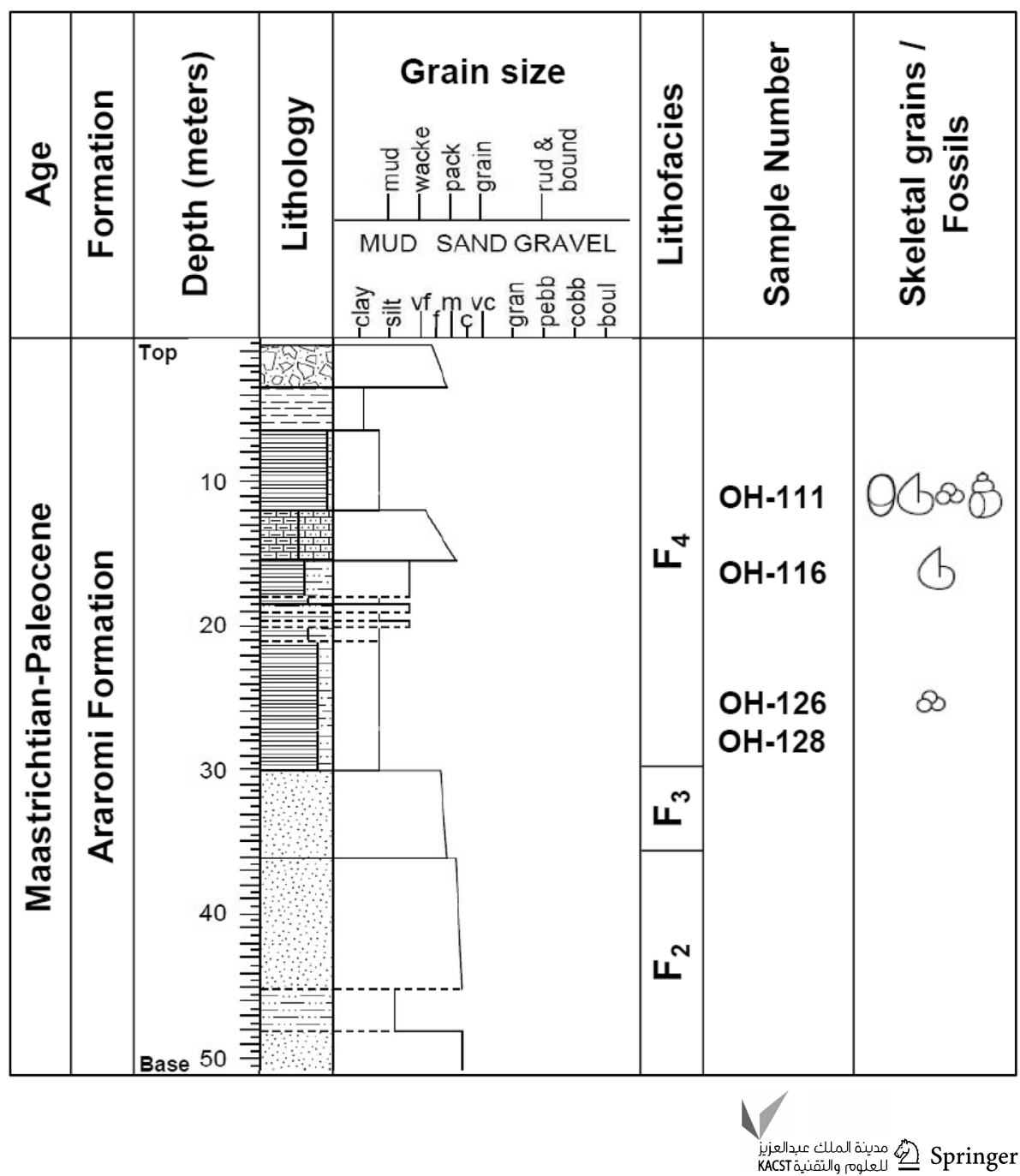


Fig. 5 Stratigraphic log showing the identified lithofacies of the Maastrichtian-Paleocene Araromi Formation in AI-2 borehole (see Fig. 1 for location, and Fig. 3 for symbols and abbreviations)

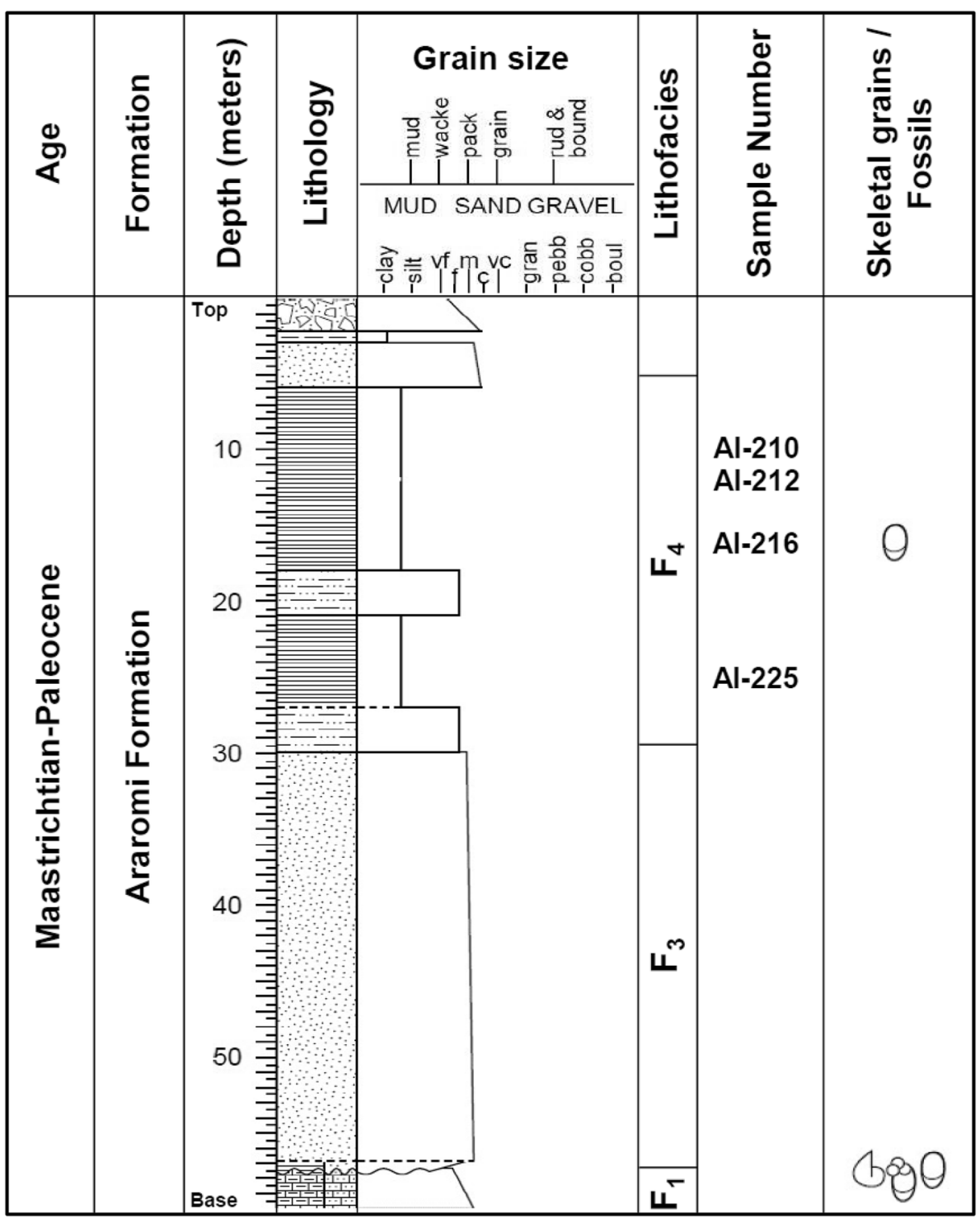

\section{Interpretation}

A lack of cross-stratification in the sandstone lithofacies suggests that the flow responsible for the deposition of the sandstone lithofacies did not maintain traction currents (Sahay et al. 2015). This facies may also have developed from a rapid deposition of suspension materials (Arnott and Hand 1989) within a fluvial system. The sandstone lithofacies $\left(\mathrm{F}_{2}\right)$ is interpreted to reflect deposition at the base of an active fluvial channel fill (Baniak and Kingsmith 2018; Adamolekun et al. 2020). The sparsely bioturbated sandstone interval reflects oxygenated to dysoxic conditions and temporary subaerial exposure. The disappearance of sandstone lithofacies $\left(\mathrm{F}_{2}\right)$ in other boreholes could be associated with lateral facies changes resulting from changes in depositional regime.

\section{Lithofacies $\left(F_{3}\right)$ : Loosely consolidated sandstone}

Description: The sandstone unit $\left(\mathrm{F}_{3}\right)$ is well-defined by massive grey, mostly medium-grained, moderately sorted, loosely consolidated sandstone (6.0-27 m thick), and observed in boreholes $\mathrm{OH}-1$ and AI-2 (Figs. 4, 5, 8a). There are no obvious bioturbation or sedimentary structures. A strong oil smell is perceived in $\mathrm{F}_{3}$ of borehole AI-2. Sedimentary structures might have been obliterated due to the loose texture.

\section{Interpretation}

The lack of sedimentary structures in loosely consolidated, moderately sorted sandstone may be due to post-depositional sediment liquefaction (Boggs 2009). The absence of 
Fig. 6 Stratigraphic log showing the identified lithofacies of the Maastrichtian-Paleocene Araromi Formation in AK-5 borehole (see Fig. 1 for location, and Fig. 3 for symbols and abbreviations)

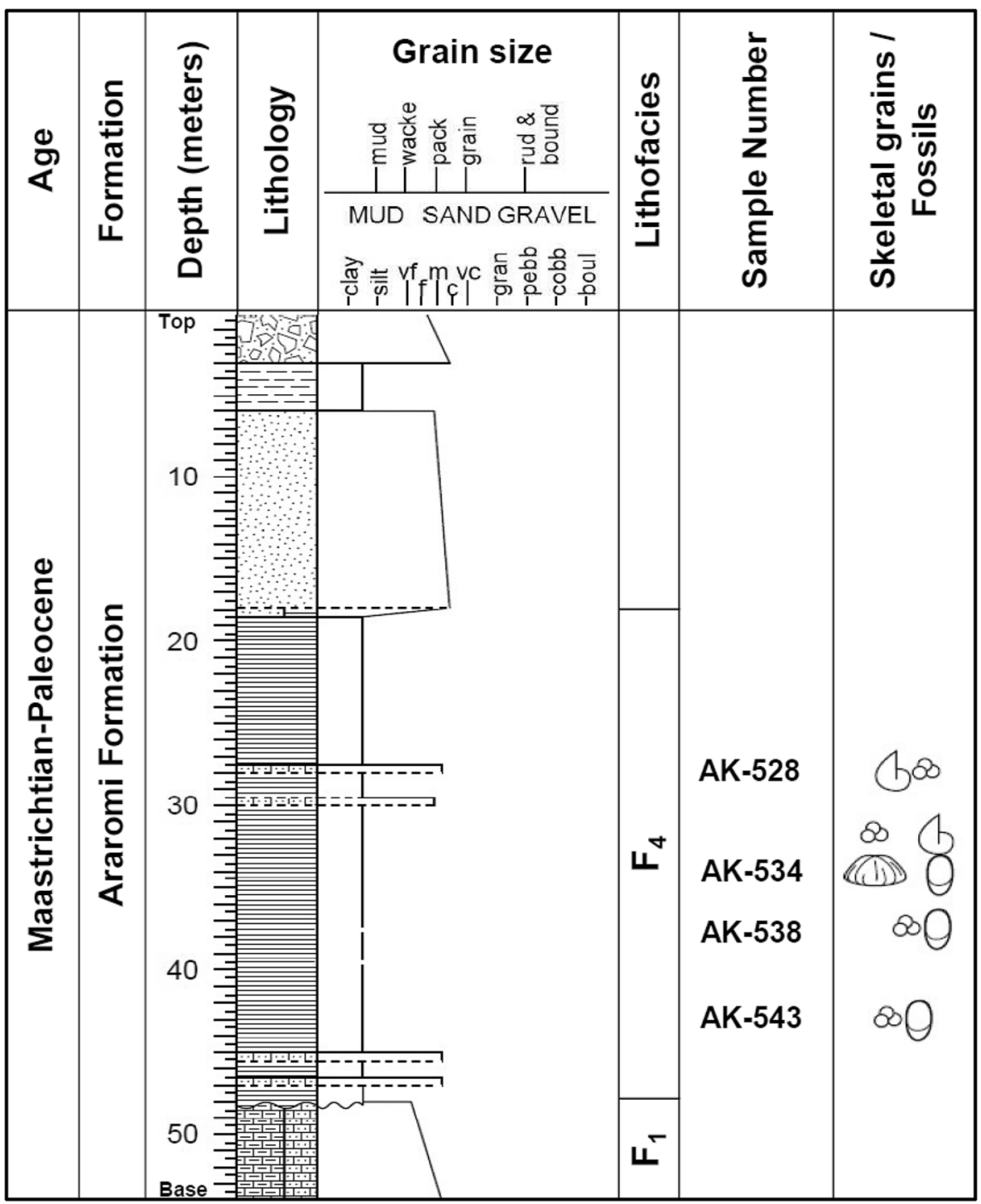

bioturbation may be due to continuous sediment deposition, i.e., with no evidence or period of subaerial exposure, and oxygen-deficient condition that inhibited biotic colonization (Boggs 2009; Kavoosi 2009; Baniak and Kingsmith 2018).

\section{Lithofacies $\left(F_{4}\right)$ : Shale and siltstone}

\section{Description}

The lithofacies $\left(\mathrm{F}_{4}\right)$ is mainly represented by the metrescale thick light to dark grey fissile, silty shale, sandy shale, and siltstone (Figs. 4-8). Oil-soaked shale and siltstone are observed in the facies. In borehole AK-5, shale and sandstone facies are intercalated with relatively thin and discontinuous limestone-rich units. Discontinuous fine-grained sandstone units and thin layers of shell fragments (near the lower limestone unit) were observed in borehole AI-2. The contact between the siltstone and the shale is generally sharp in all the boreholes.

\section{Interpretation}

This facies is largely dominated by argillaceous sediments which suggest a deposition process in low-energy conditions, punctuated by higher energy conditions caused by localized wind-induced storms (Bouma et al. 1981; Ojo and Akande 2006). Abandoned deposits are primarily siltstone and are commonly devoid of physical and biogenic sedimentary structures (Baniak and Kingsmith 2018). The observed discontinuous fine-grained sandstone lenses suggest sedimentation under short-lived high-energy pulses occasioned by localised wind storms (Wolela 2010). The relatively thin and discontinuous limestone units in this facies appear to represent the effects of sediment flushing and winnowing 
Fig. 7 Stratigraphic log showing the identified lithofacies of the Paleocene Araromi Formation in AY-8 borehole (see Fig. 1 for location, and Fig. 3 for symbols and abbreviations)

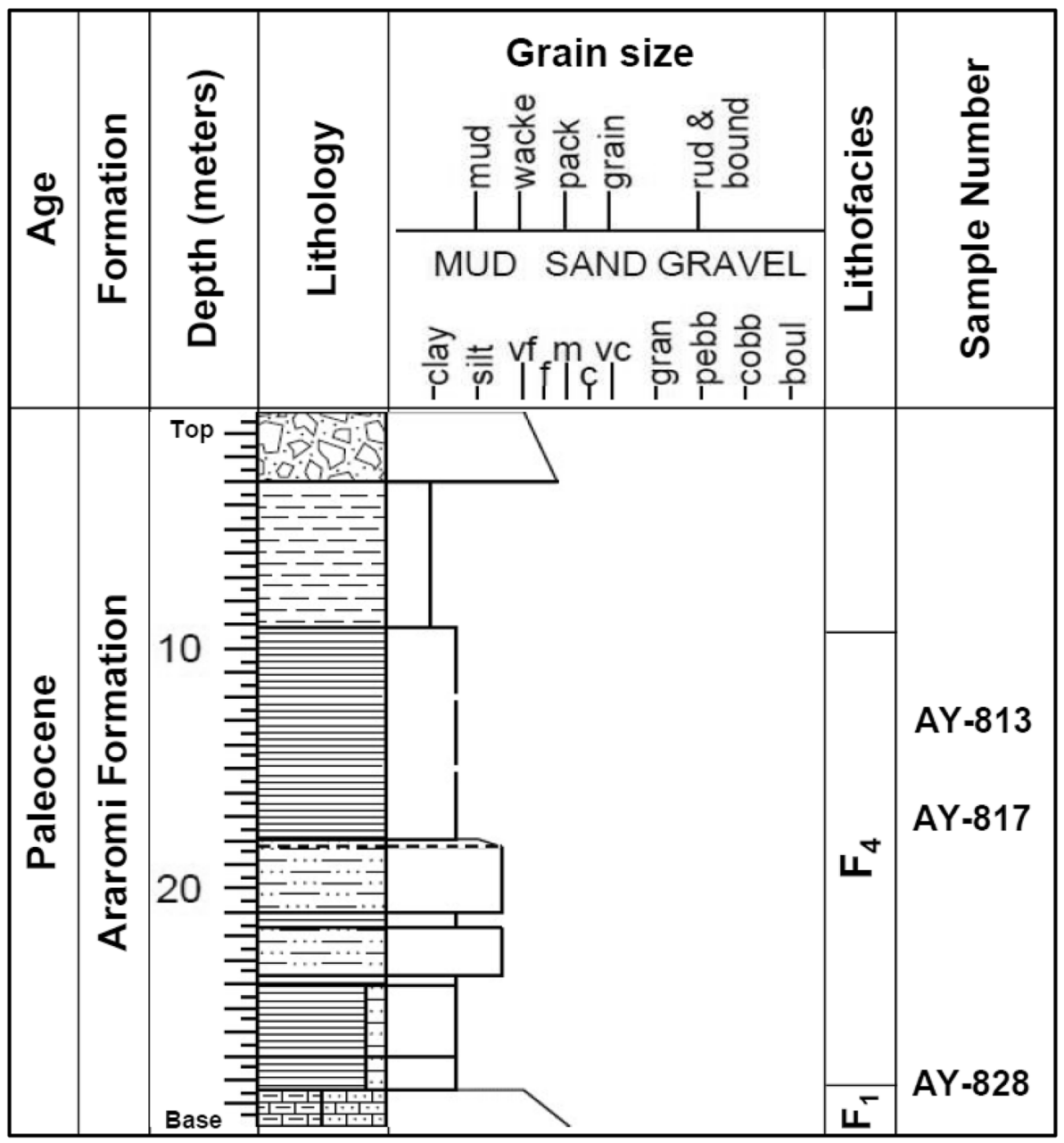

that took place as storm-generated waves passed over the shelf (Specht and Brenner 1979).

\section{Palynology}

The distributions of palynomorphs in the analyzed samples of shale and siltstone lithofacies $\left(\mathrm{F}_{4}\right)$ are shown in (Table 1) and (Table 2). The lithofacies $\left(\mathrm{F}_{4}\right)$ is marked by the presence of marine dinoflagellate cysts (Paleocystodinium sp., Senegalinium bicavatum, Palaeocystodinium australinium, Subtilisphaera sp.); terrestrial species of spores (Cingulatisporites ornatus, Cyathidites minor, Cyathidites sp., Distaverrusporites simplex, Foveotriletes margaritae); pollens (Ericipites sp., Longapertites marginatus, Longapertites microfeveolatus, Longapertites sp., Monocolpites marginatus) and Fungal spores (Figs. 9 and 10). The palynomorphs recovered from lithofacies $\left(\mathrm{F}_{4}\right)$ showed moderately rich assemblages. The palynomorph assemblage consists of well-preserved species dominated by pollen (palms), spores, and dinoflagellate cysts (Tables 1 and 2). The non-palynomorph assemblage includes acritarchs and micro-foraminiferal wall lining.
Amongst the marine dinoflagellate species from lithofacies $\left(\mathrm{F}_{4}\right)$, the peridiniods were more abundant and diverse than the gonyaulacoids, and yielded very low counts of freshwater algal spores. The marine species recovered from lithofacies $\left(\mathrm{F}_{4}\right)$ are more pronounced in boreholes AI-2, AK-5, and AY-8, while terrigenous species dominate in the borehole $\mathrm{OH}-1$ (Table 3).

\section{Total organic carbon (TOC) content}

A total of ten samples were analyzed for Total Organic Carbon (TOC). The results of LECO TOC are presented in (Table 4). The TOC values of the shale samples of the Araromi Formation range from 0.24 to $2.50 \mathrm{wt} \%$, with an average value of $1.28 \mathrm{wt} \% .70 \%$ of the samples have TOC greater than $0.5 \mathrm{wt}$ $\%$.

\section{Rock-Eval II pyrolysis results}

The programmed pyrolysis results are presented in (Table 4). The $S_{1}$ and $S_{2}$ values of the shale samples of the Araromi Formation range from 0.02 to $0.10 \mathrm{mgHC} / \mathrm{g}$ rock and 0.26 to 
Fig. 8 Photographs of part of core samples recovered from (a) Bitumen impregnated siltstone (Bsit), loosely consolidated sandstone (sst) and limestone (Lmt) at 27-60 m depth (Borehole AI-2).

(b) Bitumen-soaked siltstone (Bsit) and dark grey siltstone (slt), 21-27 m depth, (Borehole AY-8). (c) Dark grey siltstone (slt) and shale (Sh), 18-30 m depth, (Borehole OH-1). The top of the red pen indicates the top of the core box
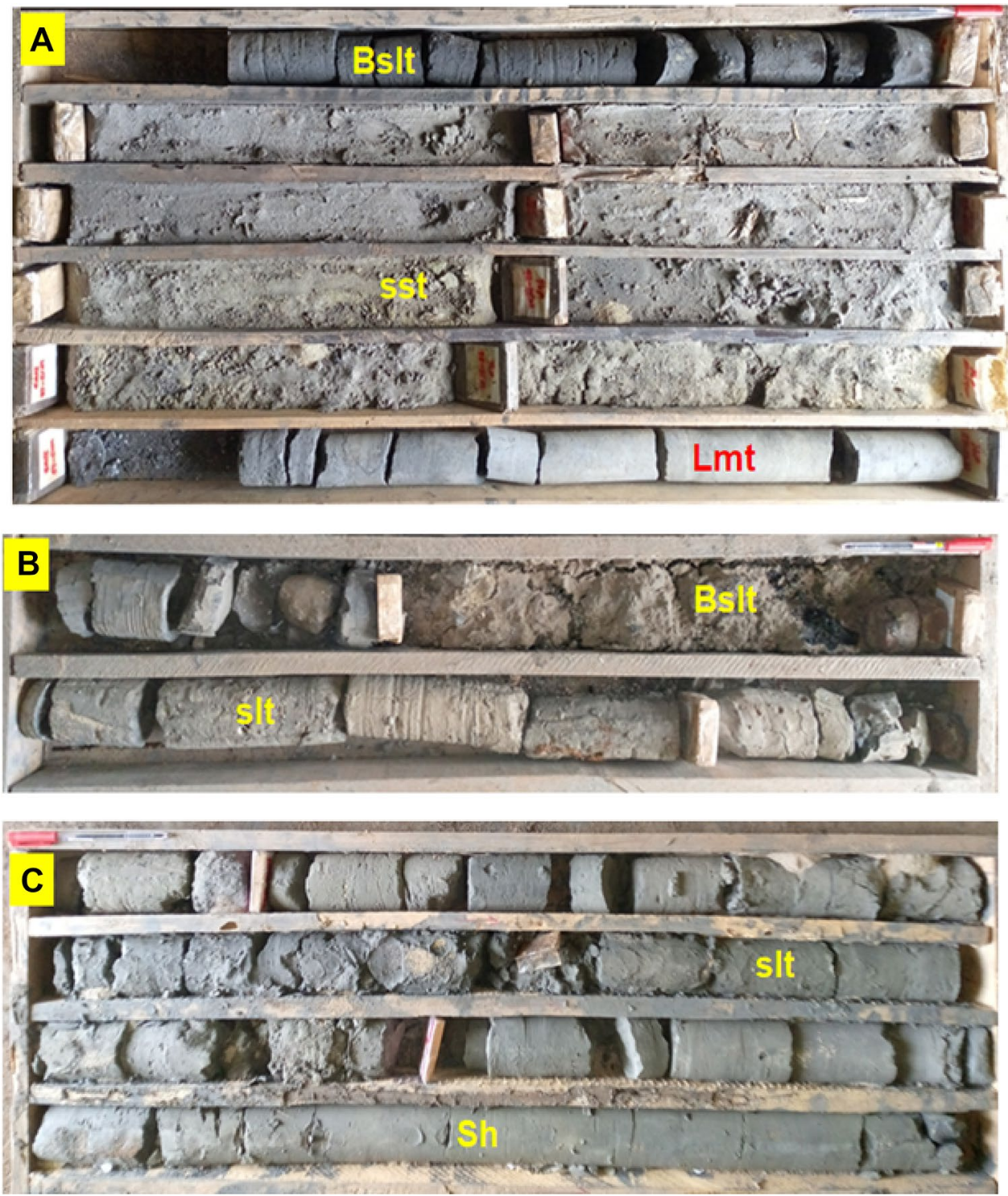

$0.70 \mathrm{mgHC} / \mathrm{g}$ rock, respectively. The values of total hydrocarbon generation potential $\left(\mathrm{S}_{1}+\mathrm{S}_{2}\right)$ of shale samples range from 0.28 to $0.73 \mathrm{mgHC} / \mathrm{g}$ rock. The $\mathrm{T}_{\max }$ values of the shale samples range from $397{ }^{\circ} \mathrm{C}$ to $425^{\circ} \mathrm{C}$ (Table 4). The hydrogen index (HI) values of shale samples of the Araromi Formation range from 16.33 to $153.51 \mathrm{mgHC} / \mathrm{g}$ TOC (Table 4) with an average value of $27.15 \mathrm{mgHC} / \mathrm{g}$ TOC. The oxygen index (OI) of the Maastrichtian-Paleocene Araromi shale samples range from 65.52 to $83.33 \mathrm{mgCO}_{2} / \mathrm{g}$ TOC and has an average value of $36.64 \mathrm{mgCO}_{2} / \mathrm{g}$ TOC. The values of the production index range from 0.04 to 0.20 . The oil saturation index (OSI) values range from 2.08 to $6.61 \mathrm{mgHC} / \mathrm{g}$ TOC (Table 4).

\section{Kerogen type}

The type of organic matter in the shale samples was determined from the Rock-Eval parameters.
The cross plots (Figs. 11 and 12) indicate that the studied shale samples fall within the type III kerogen and type IV kerogen fields. Most of the analyzed shale samples are characterised by low HI and OI values that indicate type IV kerogen.

\section{Discussions}

\section{Organic richness}

Rocks with TOC content greater than $1.0 \mathrm{wt} \%$ are considered fair quality source rocks (Dembicki 2016; Meilijson et al. 2020). Six out of ten shale samples have TOC values greater than $1.0 \mathrm{wt} \%$. The studied shale samples of the Araromi Formation are characterized by fair TOC values (Table 4), (Fig. 13). The generally low TOC values reflect

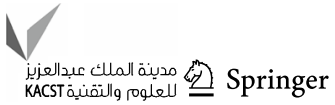


Table 1 The abundance of terrigenous species (pollen, spores, and fungal remains) in each analyzed shale samples

\begin{tabular}{|c|c|c|c|c|c|c|c|c|c|c|c|c|c|c|c|}
\hline \multirow{2}{*}{$\begin{array}{l}\text { Borehole } \\
\text { Depth, m }\end{array}$} & \multicolumn{4}{|c|}{ OH-1 } & \multicolumn{4}{|c|}{ AI-2 } & \multicolumn{4}{|c|}{ AK-5 } & \multicolumn{3}{|c|}{ AY-8 } \\
\hline & 11 & 16 & 26 & 28 & 10 & 12 & 16 & 25 & 28 & 34 & 38 & 43 & 13 & 17 & 28 \\
\hline \multicolumn{16}{|l|}{ Terrigenous species } \\
\hline \multicolumn{16}{|l|}{ Pollen (Palms) } \\
\hline Echitriporites trianguliformis & & & & & & & & 1 & & & & & & & \\
\hline \multicolumn{16}{|l|}{ Epherdripites sp. } \\
\hline Ericipites spp & 3 & 1 & & & & & & & & & & & & & \\
\hline Longapertites marginatus & 15 & 3 & 1 & 1 & & & & & & & & & & & \\
\hline Longapertites microfeveolatus & & & 1 & & & & & & & & & 2 & & 1 & \\
\hline Longapertites sp. & 15 & 1 & 1 & 3 & 1 & & & 3 & & & 2 & & 1 & 1 & 1 \\
\hline Monocolpites marginatus & 15 & 10 & 6 & 2 & & 1 & & 1 & & & 1 & & 1 & & 1 \\
\hline Monocolpopollenites sphaeroidites & & & & & & & & & & & 1 & & & & \\
\hline Proteacidites sigalii & & & & & & & & & & & & 1 & & & \\
\hline Proteacidites sp. & & 1 & & & & & & 1 & & & & & & & \\
\hline \multicolumn{16}{|l|}{ Proxapertites cursus } \\
\hline Retidiporites magdalenensis & & & & & & & & & & & & 1 & & & \\
\hline \multicolumn{16}{|l|}{ Retidiporites sp. } \\
\hline Spinizonocolpites baculatus & & & & & & & & 1 & & & & & & & \\
\hline \multicolumn{16}{|l|}{ Spores } \\
\hline Charred Gramineae cuticle & & & & & & & & & & & 1 & & & & \\
\hline \multicolumn{16}{|l|}{ Cicatricosisporites sp. } \\
\hline Cingulatisporites ornatus & 2 & 3 & 1 & 1 & 2 & & & & 1 & & & & & & \\
\hline Cyathidites minor & 10 & 1 & 4 & & 4 & & 1 & 5 & 2 & & 2 & 6 & 15 & 5 & \\
\hline Cyathidites sp. & & 1 & & & & & & & & & & & & 2 & \\
\hline Distaverrusporites simplex & 3 & & & & & & & 1 & & & & & & & \\
\hline Foveotriletes margaritae & & 1 & & & & & & 1 & & & & & 1 & & \\
\hline Laevigatisporites haarditii & & & & & & & & & & 2 & & & & & \\
\hline \multicolumn{16}{|l|}{ Laevigatosporites sp. } \\
\hline Lycopodiumsporites sp. & & 1 & & & & & & & & & & & & & \\
\hline Retimonocolpites sp. & & & & & & & & & & & & & 1 & & \\
\hline Rugulatisporites caperatus & 1 & & & & & & & 1 & & & & & 1 & & \\
\hline Simple monolete spore & & & & & & & & & & & & 2 & & & \\
\hline Verrucatosporites sp. & & & & & 1 & & & & & & & & & & \\
\hline Verrucatosporites unmensis & & & & & & & & & & & & & 1 & & \\
\hline \multicolumn{16}{|l|}{ Fungal Remains } \\
\hline Fungal spore & & & & & & 2 & 1 & & & 2 & & & & & \\
\hline
\end{tabular}

an increased dilution of nearly a constant supply of terrestrial organic matter, resulting in greater oxidation, selective winnowing, and transport of organic matter to less turbulent environments (Bustin et al. 1985; Bustin 1988).

\section{Organic matter provenance}

The cross plots (Figs. 11 and 12) indicate that the analyzed shale samples are placed within type III (terrestrial and gas prone) and type IV (biodegraded and inert) kerogen fields. This reflects a terrigenous provenance for the shale samples (Ojo et al. 2020; Sachsenhofer et al. 2017; Meilijson et al. 2020) and that the organic matter of the shale samples of the Araromi Formation is extensively recycled and to a relatively lesser extent altered by catagenetic processes (Ehinola et al. 2005; Meilijson et al. 2020).

\section{Hydrocarbon potential}

The volume of hydrocarbons that formed during thermal pyrolysis $\left(\mathrm{S}_{2}\right)$ is less than $2 \mathrm{mgHC} / \mathrm{g}$ rock (Table 4 ). This implies that there is no significant remaining source rock potential for the samples (Çiftçi et al. 2010). Though the TOC content and the plots of the genetic potential $\left(\mathrm{S}_{1}+\mathrm{S}_{2}\right)$ versus TOC (Fig. 13; Peters 1986) of the rocks allow its classification as poor to 
Table 2 The abundance of marine species in each analyzed shale samples

\begin{tabular}{|c|c|c|c|c|c|c|c|c|c|c|c|c|c|c|c|}
\hline \multirow{2}{*}{$\begin{array}{l}\text { Borehole } \\
\text { Depth, m }\end{array}$} & \multicolumn{4}{|c|}{ OH-1 } & \multicolumn{4}{|c|}{$\mathrm{AI}-2$} & \multicolumn{4}{|c|}{ AK-5 } & \multicolumn{3}{|c|}{ AY-8 } \\
\hline & 11 & 16 & 26 & 28 & 10 & 12 & 16 & 25 & 28 & 34 & 38 & 43 & 13 & 17 & 28 \\
\hline
\end{tabular}

Marine species

Dinoflagellate cysts

Achomosphaera sp.

Apectodinium tectanum

Areosphaeridium sp.

Cerodinium diebeli

Cerodinium striatum

Deflandrea sp.

Lejeunecysta sp.

Odontochitina sp.

Oligosphaeridium sp.

Palaeocystodinium australinium

Paleocystodinium sp.

Senegalinium bicavatum

Senegalinium sp.

Subtilisphaera sp.

Gonyaulacoids

Cleistosphaeridium sp.

Gymnodinium acuminatum

Hystrichosphaeridium sp.

Prasinophytic Algae

Botryococcus braunii

4

Acritarch

Leiosphaeridia sp.

15

Microforaminiferal wall lining

Foraminiferal wall lining

$\begin{array}{llll}1 & 2 & 2 & 2 \\ 4 & & \end{array}$
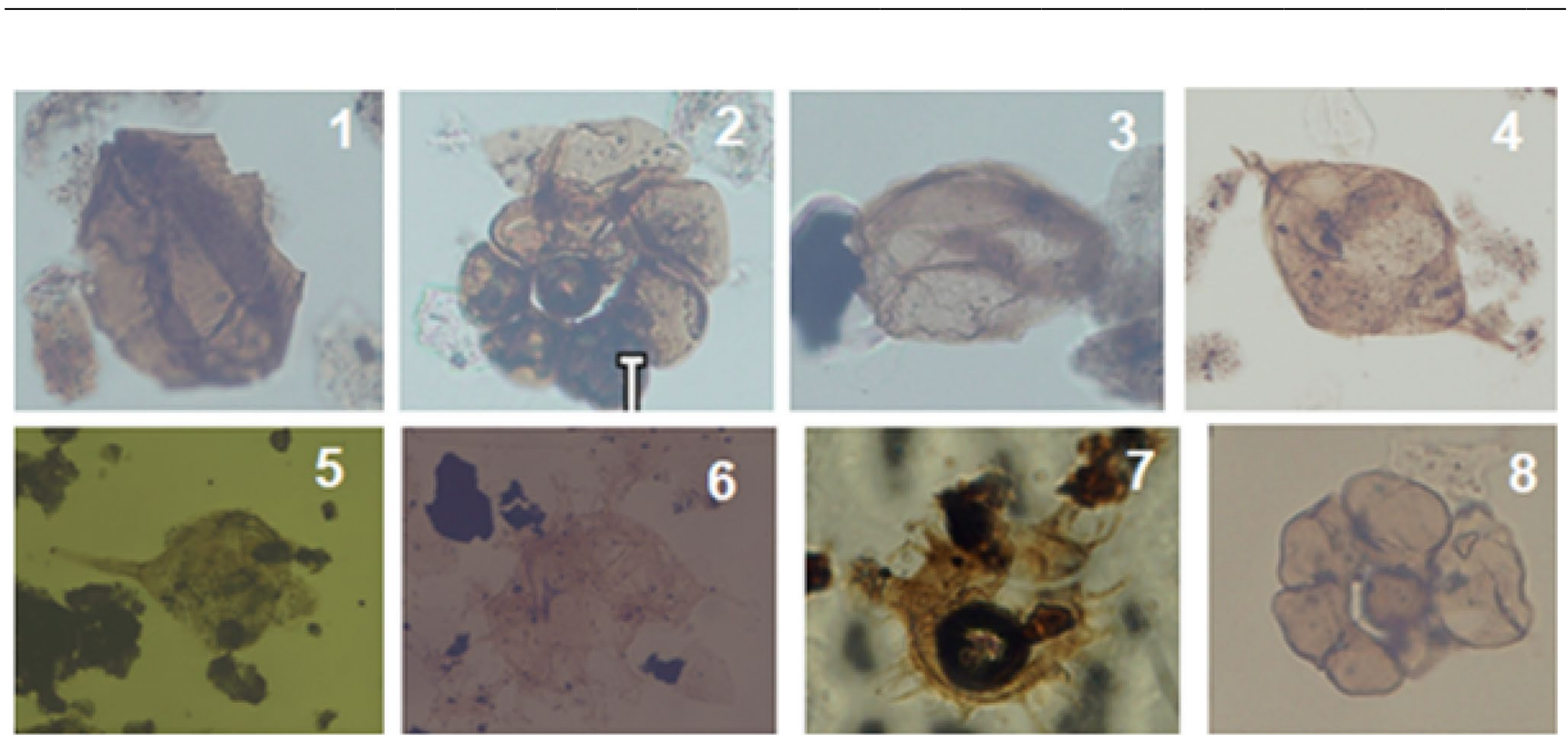

Fig. 9 Photomicrographs of palynomorph species recovered from Paleocene Shale of Araromi Formation in borehole AY-8. Magnification $(\times 100)$. 1. Senegalinium spp. (AY-817), 2. Microforaminifera wall lining (AY-817), 3. Leiosphaeridia spp. (AY-825), 4. Palaeocys-

todinium spp. (AY-825), 5. Paleiocystodinium australinium (AY-828), 6. Oligosphaeridium spp. (AY-828), 7. Hystrichodinium spp. (AY828), 8. Microforaminiferal wall lining (AY-828). The red pen indicates the top of the core box 

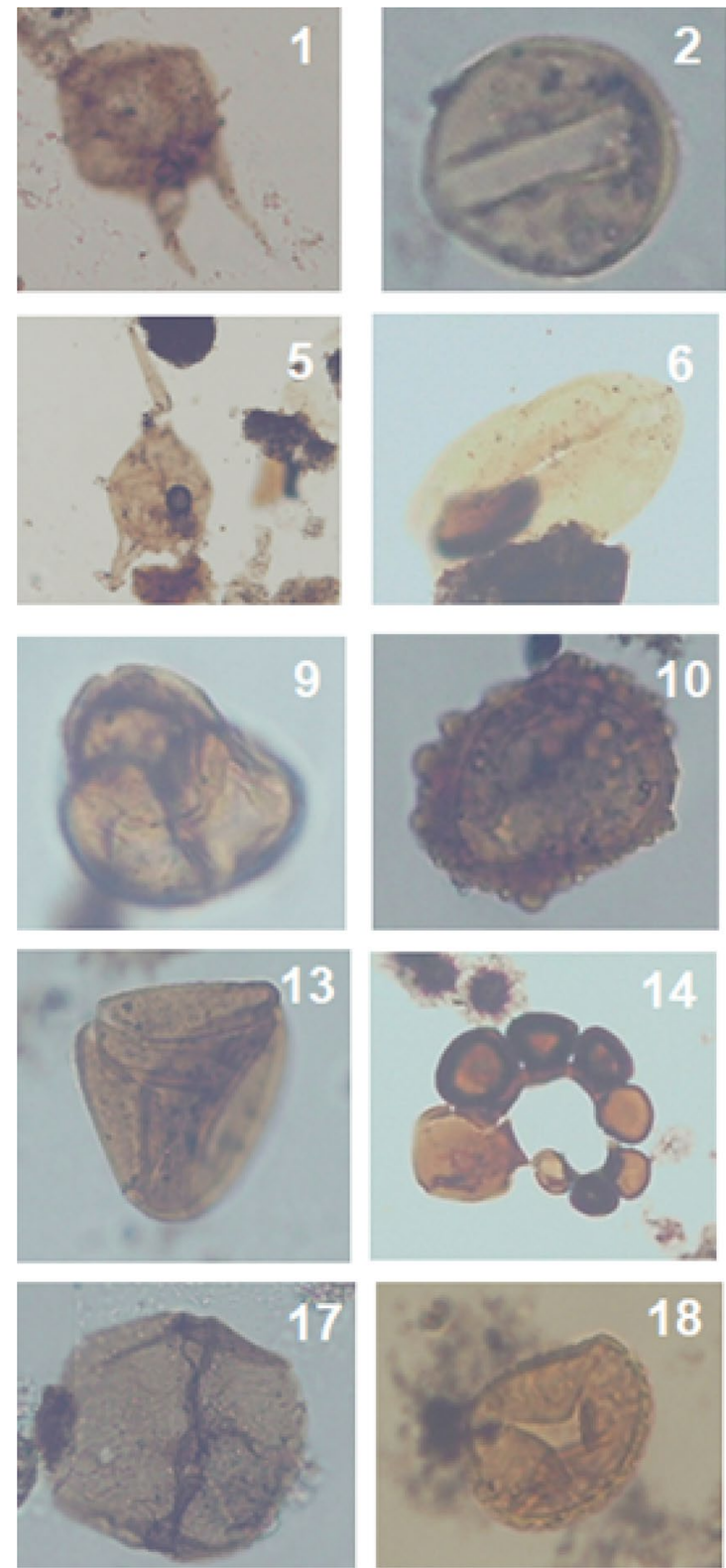

Fig. 10 Photomicrographs of palynomorph assemblages recovered from Maastrichtian-Paleocene shale samples of Araromi Formation in boreholes $\mathrm{OH}-1, \mathrm{AI}-2$, and AY-8. Magnification $(\times 100)$. Cerodinium diabeli $(\mathrm{OH}-111), 2$. Monocolpites marginatus $(\mathrm{OH}-$ 111), 3. Longapertites marginatus (OH-116), 4. Cerodinium diabeli (OH-116), 5. Cerodinium diabeli $(\mathrm{OH}-126)$, 6. Longapertites microfoveolatus (OH-126), 7. Monocolpites marginatus (OH-128), 8. Palaeocystodinium spp. (OH-128), 9. Ericipites spp. (OH-111), 10. Dis-

excellent source rock, nonetheless, the shale samples have poor hydrocarbon potential based on the genetic potential.

\section{Organic matter maturity}

The range of $\mathrm{T}_{\max }$ values $\left(397\right.$ and $425{ }^{\circ} \mathrm{C}$ ) of the shale samples, is indicative of thermally immature source rocks
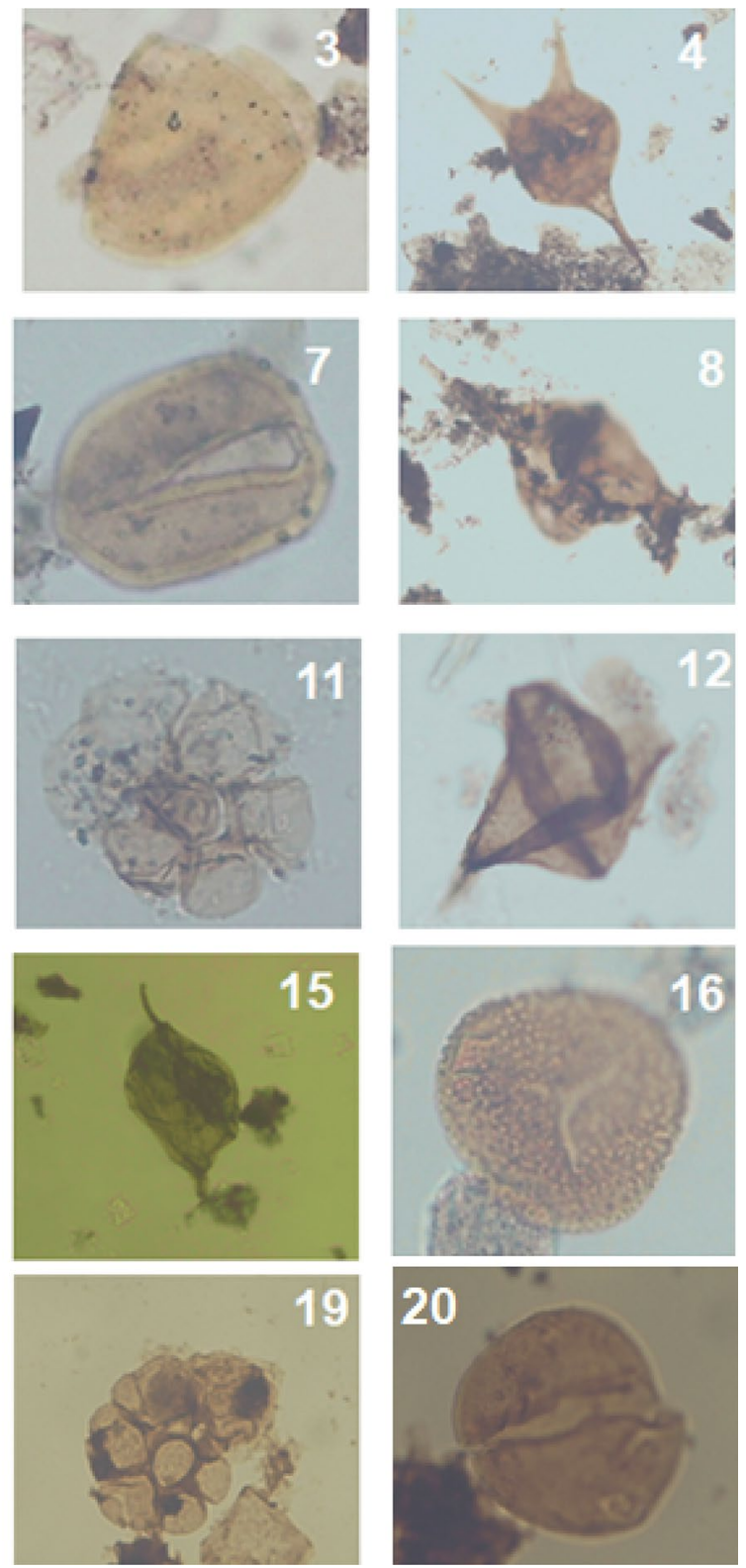

taverrusporites simplex $(\mathrm{OH}-111)$, 11. Microforaminiferal wall lining (AI-212), 12. Subtilisphaera spp. (AI-216), 13. Cyathidites minor (AI-216), 14. Microforaminiferal wall lining (AI-225), 15. Paleiocystodinium australinium (AI-258), 16. Foveotriletes margaritae (AY813), 17. Senegalinium spp. (AY-813), 18. Rugulatisporites caperatus (AY-813), 19. Microforaminiferal wall lining (AY-813), 20. Monocolpites marginatus (AY-828)

and low thermal conversion condition for hydrocarbon generation and expulsion in the basin (Fig. 14), (Ehinola et al. 2005; Çiftçi et al. 2010; Wolela 2010). It therefore appears that the shale of the Araromi Formation was not buried deep enough for intense thermal alteration and hydrocarbon production (Sachsenhofer et al. 2017; Ojo et al. 2020). The analyzed samples show low oil saturation index (OSI) and 
Table 3 The abundance (Percentage) of various palynomorph groups

\begin{tabular}{|c|c|c|c|c|c|c|c|c|c|c|c|c|c|c|c|}
\hline \multirow[t]{2}{*}{ Palynomorph groups } & \multicolumn{4}{|c|}{$\mathrm{OH}-1$} & \multicolumn{4}{|l|}{ AI-2 } & \multicolumn{4}{|c|}{ AK-5 } & \multicolumn{3}{|l|}{ AY-8 } \\
\hline & 111 & 116 & 126 & 128 & 210 & 212 & 216 & 225 & 528 & 534 & 58 & 543 & 813 & 817 & 828 \\
\hline Pollen (Palms) & 47.1 & 43.2 & 40.9 & 66.7 & 2.2 & 5.3 & 0.0 & 17.5 & 0.0 & 0.0 & 27.3 & 10.9 & 2.4 & 9.5 & 5.7 \\
\hline Spores & 15.7 & 18.9 & 22.7 & 11.1 & 15.6 & 0.0 & 14.3 & 20.0 & 37.5 & 16.7 & 18.2 & 17.4 & 23.2 & 33.3 & 0.0 \\
\hline Fungal Remains & 0.0 & 0.0 & 0.0 & 0.0 & 0.0 & 10.5 & 14.3 & 0.0 & 0.0 & 16.7 & 0.0 & 0.0 & 0.0 & 0.0 & 0.0 \\
\hline \multicolumn{16}{|l|}{ Dinoflagellate Cysts } \\
\hline Peridiniods & 14.7 & 32.4 & 31.8 & 11.1 & 22.2 & 42.1 & 42.9 & 12.5 & 12.5 & 41.7 & 36.4 & 13.0 & 31.7 & 23.8 & 62.9 \\
\hline Gonyaulacoids & 0.0 & 0.0 & 0.0 & 0.0 & 0.0 & 0.0 & 0.0 & 0.0 & 0.0 & 8.3 & 0.0 & 0.0 & 3.7 & 0.0 & 5.7 \\
\hline Prasinophytic Algae & 3.9 & 0.0 & 0.0 & 0.0 & 0.0 & 0.0 & 0.0 & 0.0 & 0.0 & 0.0 & 0.0 & 0.0 & 0.0 & 0.0 & 0.0 \\
\hline Acritarch & 14.7 & 0.0 & 0.0 & 0.0 & 53.3 & 15.8 & 14.3 & 42.5 & 25.0 & 0.0 & 9.1 & 26.1 & 36.6 & 23.8 & 0.0 \\
\hline Microforaminiferal wall lining & 3.9 & 5.4 & 4.5 & 11.1 & 6.7 & 26.3 & 14.3 & 7.5 & 25.0 & 16.7 & 9.1 & 32.6 & 2.4 & 9.5 & 25.7 \\
\hline
\end{tabular}

Table 4 Results of Rock-Eval Pyrolysis and Total Organic Carbon Content analyses with calculated parameters of the Maastrichtian-Paleocene Araromi shale samples

\begin{tabular}{|c|c|c|c|c|c|c|c|c|c|c|c|c|c|}
\hline Borehole & Sample Number & Depth, (m) & TOC & $\mathrm{S}_{1}$ & $\mathrm{~S}_{2}$ & $\mathrm{~S}_{3}$ & $\mathrm{~S}_{1}+\mathrm{S}_{2}$ & $\mathrm{~S}_{2} / \mathrm{S}_{3}$ & $\mathrm{~T}_{\max }$ & HI & OI & PI & OSI \\
\hline $\mathrm{OH}-1$ & $\mathrm{OH}-111$ & 11 & 1.96 & 0.04 & 0.32 & 1.45 & 0.36 & 0.22 & 407.00 & 16.33 & 73.98 & 0.11 & 2.08 \\
\hline $\mathrm{OH}-1$ & $\mathrm{OH}-116$ & 16 & 1.04 & - & & & & & & & & & \\
\hline $\mathrm{OH}-1$ & $\mathrm{OH}-126$ & 26 & 0.48 & - & & & & & & & & & \\
\hline AI-2 & AI-208 & 8 & 0.24 & - & & & & & & & & & \\
\hline AI-2 & AI-212 & 12 & 0.46 & - & & & & & & & & & \\
\hline AI-2 & AI-227 & 27 & 2.50 & 0.10 & 0.41 & 1.76 & 0.51 & 0.23 & 397.00 & 16.37 & 70.26 & 0.20 & 4.05 \\
\hline $\mathrm{AK}-5$ & AK-524 & 28 & 0.69 & & & & - & & & & & & \\
\hline AK-5 & AK-540 & 40 & 0.84 & 0.02 & 0.26 & 0.55 & 0.28 & 0.47 & 412.00 & 30.97 & 65.52 & 0.07 & 2.38 \\
\hline AY -8 & AY-813 & 13 & 1.41 & - & & & & & & & & & \\
\hline AY-8 & AY-828 & 28 & 0.60 & 0.03 & 0.70 & 0.38 & 0.73 & 1.84 & 425.00 & 153.51 & 83.33 & 0.04 & 6.61 \\
\hline
\end{tabular}

“-” Not measured; TOC Total organic carbon (wt. \%); $\mathbf{S}_{\mathbf{1}}$ Volatile hydrocarbon (HC) content, $\mathrm{mgHC} / \mathrm{g}$ rock; $\mathbf{S}_{\mathbf{2}}$ Remaining HC generative potential, $\mathrm{mgHC} / \mathrm{g}$ rock; $\mathbf{S}_{\mathbf{3}}$ Organic carbon dioxide content, $\mathrm{mgCO}_{2} / \mathrm{g}$ rock; $\mathbf{S}_{\mathbf{1}}+\mathbf{S}_{\mathbf{2}}$ Total generation potential; $\mathbf{T}_{\max }$ Temperature at which the maximum generation of the hydrocarbons occurs $\left({ }^{\circ} \mathrm{C}\right)$; $\mathbf{H I}$ Hydrogen index $\left(\mathrm{S}_{2} / \mathrm{TOC} * 100\right)$, measured in mgHC/g TOC; OI Oxygen index $\left(\mathrm{S}_{3} /\right.$ TOC*100), measured in $\mathrm{mg} \mathrm{CO} / \mathrm{g}$ TOC; PI Production index, $\mathrm{S}_{1} /\left(\mathrm{S}_{1}+\mathrm{S}_{2}\right)$; OSI $\mathrm{S}_{1} / \mathrm{TOC}^{*} 100, \mathrm{mgHC} / \mathrm{g}$ TOC

Production index (PI), indicative of low oil saturation and thermally immature source rocks, respectively (Table 4), (Fig. 14), (Jarvie 2012; Hafiz et al. 2020).

\section{Depositional environment}

This study integrates the results of sedimentological and palynological analyses to infer the paleo-depositional environment. The results of sedimentological logging indicate that deposition of the Araromi Formation occurred mainly in fluvial and shallow-marine (shelf) environments.

Palynological analyses indicate the presence of Leiosphaeridea sp., and foraminiferal wall lining in nearly all the analyzed shale and siltstone $\left(\mathrm{F}_{4}\right)$ samples suggest marine flooding in nearshore or brackish water (Okeke and Umeji 2016; Bolaji et al. 2020). Monocolpites marginatus and Cyathidites minor recovered in all the shale and siltstone $\left(\mathrm{F}_{4}\right)$ samples suggest a brackish to freshwater influence (Okeke and Umeji 2016). The influence of shallow-marine conditions is indicated by the presence of peridiniods-Paleocystodinium sp. and Senegalinium sp. assemblage in the samples (Ojo and Akande 2006; Bolaji et al. 2020).

The dominance of terrestrial palynomorph species over marine species was observed in shale samples $\left(\mathrm{F}_{4}\right)$ of borehole $\mathrm{OH}-1$, towards the east of the study area (Table 3 ), this reflects sea level drop and indicates proximity to the continent (Sachsenhofer et al. 2017). Moreover, the population of marine palynomorphs shows an increase in shale and siltstone $\left(\mathrm{F}_{4}\right)$ samples obtained from boreholes AI-2, AK-5, and AY-8 (Table 3). The predominance of marine dinocysts over continental-derived pollen and spores indicate that the continental-derived materials were intermittently introduced into the marine depositional environment either through 
Fig. 11 Graphical presentation of the Rock-Eval pyrolysis results for shale samples of Araromi Formation, eastern Dahomey (Benin) Basin. The plot indicates type III and type IV kerogen

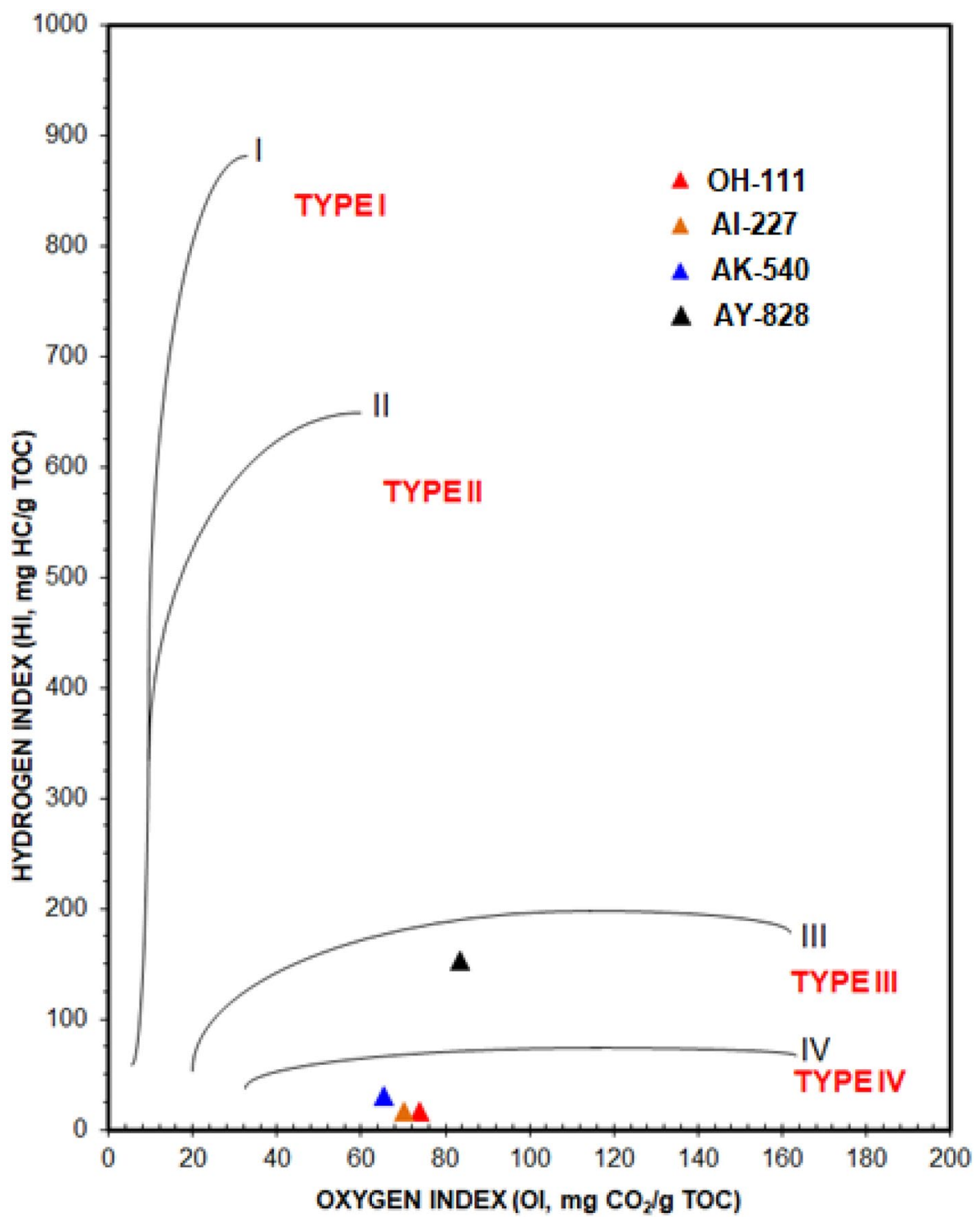

river-lake systems or floods caused by intermittent heavy rainfalls (Bankole et al. 2006).

\section{Implications for hydrocarbon exploration}

The TOC values vary from 0.24 to $2.50 \mathrm{wt} \%$ indicating fair to very good source rock. However, shale samples have poor hydrocarbon potential based on the genetic potential. The low TOC values (and also HI values) in some shale samples may have occurred as a result of sediment dilution, selective transport, and oxidation of the organic matter (Bustin 1988).

The HI values of organic-rich shale samples are generally low ( $<100 \mathrm{mg} \mathrm{HC/g}$ TOC), and could be attributed to high organic productivity but poor preservation condition and scarcity of lipid-rich marine zooplanktons (Ojo et al. 2020). Pervasive oxidation and extensive grazing under oxic conditions would lead to hydrogen depletion in the organic materials and therefore low HI (Ojo et al. 2020). The plot of $\mathrm{HI}$ versus OI indicates that the shale samples contain types III and IV organic matter. However, the effect of oxidation or mineral matrix effect on the kerogen cannot be ruled out as reasons for its poor quality. Liptinites can be converted into inertinites during oxidation (Ehinola et al. 2005).

The eastern Dahomey Basin is believed to be sourced by in situ interbedded Maastrichtian limestone and shale (Adegoke et al. 1980; Coker 1982). However, analyzed shales are immature for oil generation at the present shallow depth (not exceeding $60 \mathrm{~m}$ depth). Hence, a significant hydrocarbon is expected from the deep-water system of the eastern Dahomey (Benin) Basin where sufficient sediment thickness has attained maturity (Macgregor et al. 2003). Oil generated at greater depths would have migrated up-dip through basement wash and fault zone; the absence of adequate trap and seal conditions coupled with the combined effects of 


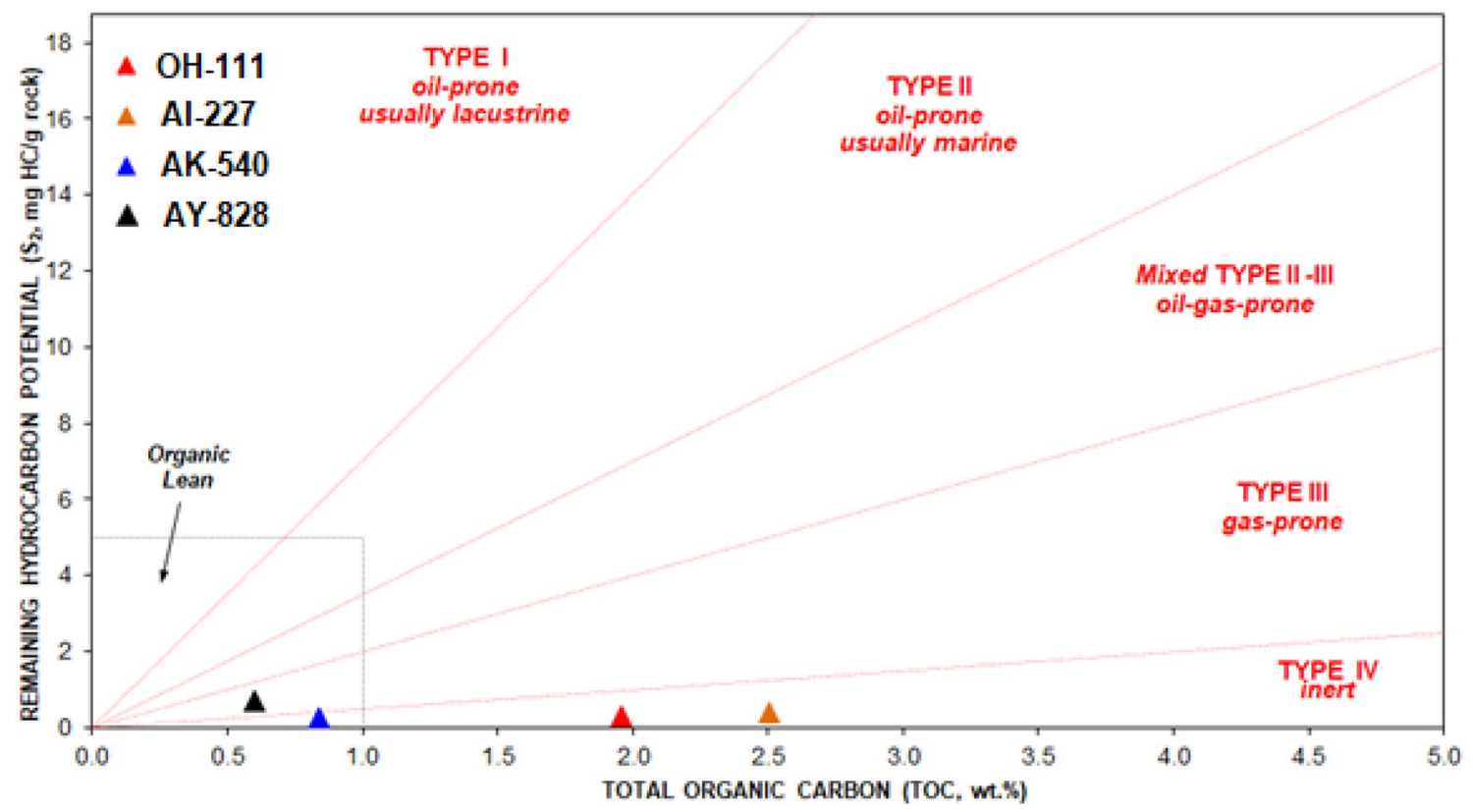

Fig. 12 Graphical presentation of remaining hydrocarbon potential $\left(\mathrm{S}_{2}\right)$ versus total organic carbon (TOC). The graph to corroborate the kerogen types is indicated in Fig. 6

Fig. 13 Cross plot of $S_{1}+S_{2}$ (total hydrocarbon generation potential) versus total organic carbon (TOC) for the analyzed samples showing poor to excellent source rocks

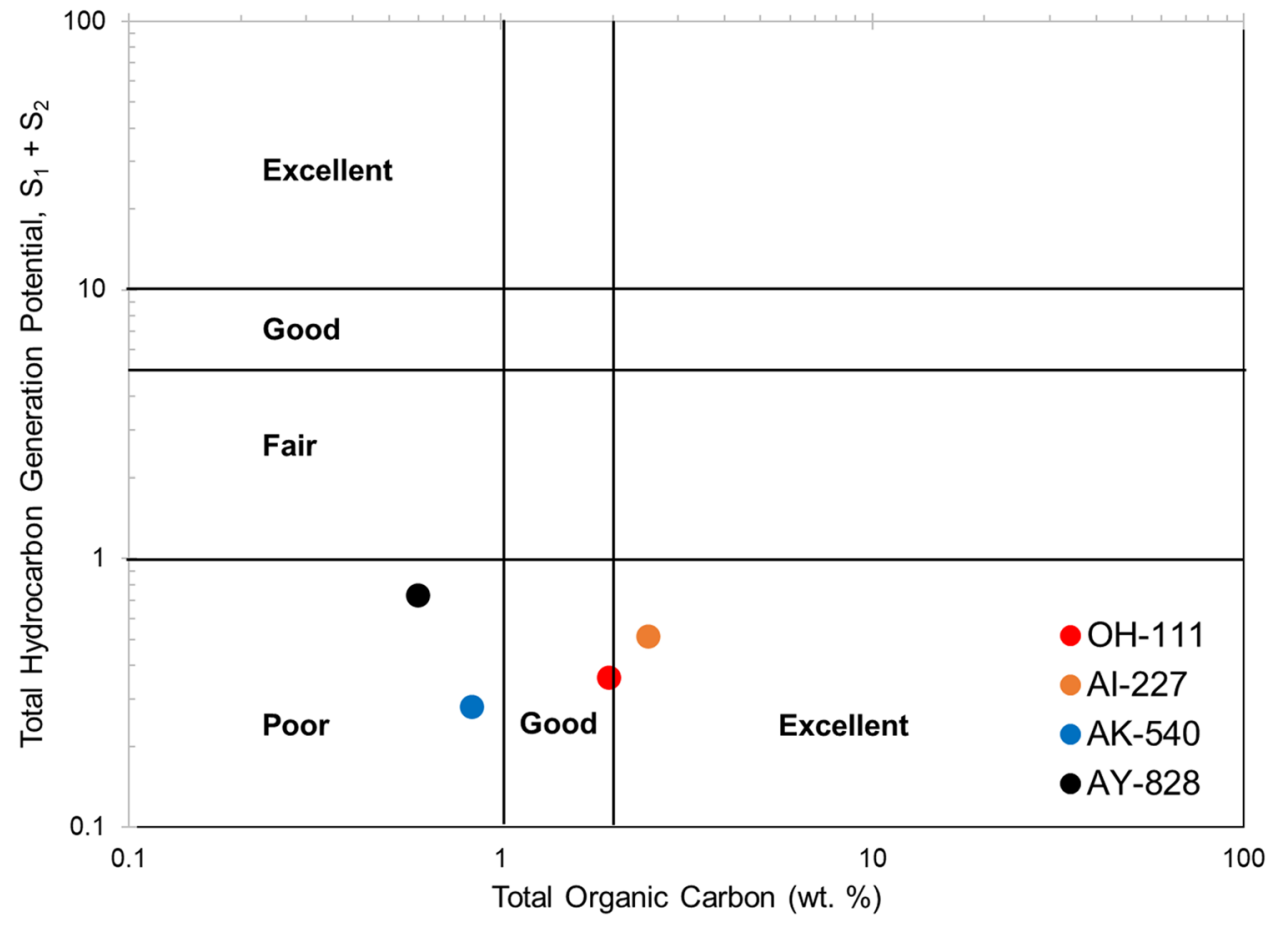

oxidation, water washing, and bacterial attack of the original oil in place have resulted in the shallow emplacement of heavy oils in the belt (Coker et al. 2002; Macgregor et al. 2003).

\section{Conclusions}

The integration of detailed sedimentological logging, palynological and geochemical studies, to interpret the depositional 
Fig. 14 A Plot of PI vs. $\mathrm{T}_{\max }$ used to determine the maturity phase of the shale samples

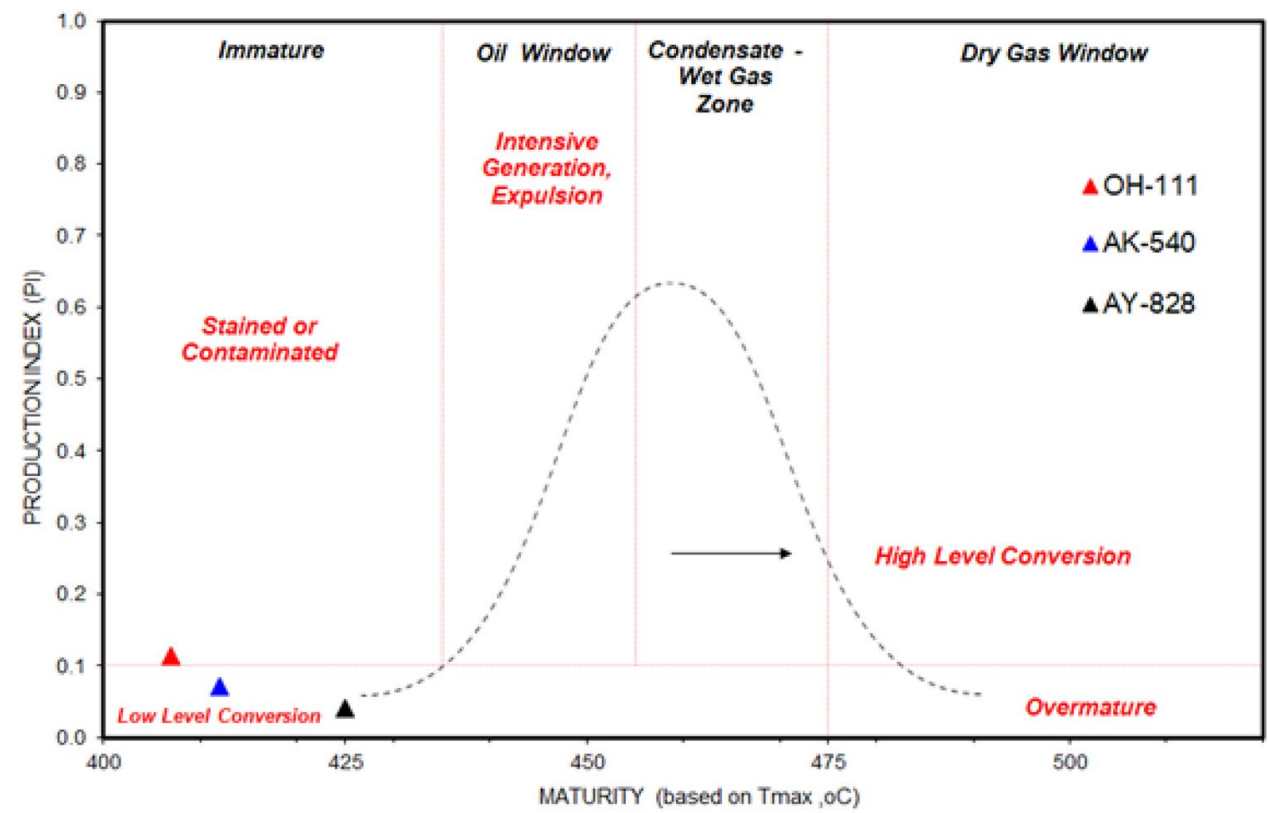

environments and assess the petroleum generation potential of Maastrichtian-Paleocene strata of the eastern Dahomey (Benin) Basin allows for the following conclusions:

1. Based on core data and exposed outcrop sections, four sedimentary lithofacies are identified, namely, basal limestone facies $\left(\mathrm{F}_{1}\right)$; medium to coarse-grained sandstone $\left(\mathrm{F}_{2}\right)$; loosely consolidated sandstone $\left(\mathrm{F}_{3}\right)$; and shale and siltstone $\left(\mathrm{F}_{4}\right)$.

2. The relationship between the facies deposits is interpreted to reflect sedimentation in fluvial and shallowmarine depositional environments. The palynological assemblages of the Araromi Formation reflect depositional environments ranging from coastal through brackish water to shallow shelf environments with periods of localized wind-induced storms.

3. The kerogen contents of the Maastrichtian-Paleocene Araromi Shales are classified as type III and type IV, with total organic carbon (TOC) content ranging from 0.24 to $2.50 \mathrm{wt}$. \%. This indicates a fair to very good source rock with little or no potential to generate oil at the present depth. Thus, the shale samples possess low source rock potentials. The hydrogen index (HI) values of the shale samples range from 16.33 to 153.51 $\mathrm{mgHC} / \mathrm{g}$ TOC, suggesting predominantly terrigenous provenance.

4. The pyrolysis temperature $\left(\mathrm{T}_{\max }\right)$ values of the analyzed shales range from 394 to $25{ }^{\circ} \mathrm{C}$ and production index (PI) values range from 0.04 to $0.20 \mathrm{mgHC} / \mathrm{g}$ rock, which indicates that they are thermally immature organic matter at the present shallow depth. This could neither have generated liquid hydrocarbon nor contributed to the heavy oil and bitumen present in the bitumen and tarsand belt of the eastern Dahomey (Benin) Basin.

5. Therefore, exploration successes in the basin would require the discovery of deeper areas, especially the western fringe of the Niger Delta Basin, that would provide enough burial depths and temperature required for source rock maturity as well as other play elements.

Acknowledgements The authors express gratitude to the Nigerian Geological Survey Agency who made borehole core samples from the bitumen belt of eastern Dahomey (Benin) Basin available for this study. Digital topography has been provided by Olusola Olayinka. We are also grateful to Crystal Age Limited, Lagos, Nigeria for providing the facilities necessary for the palynological analysis. Activation Laboratories Ltd. (ACTLAB), Ontario, Canada carried out the Total Organic Carbon/Programmed Rock-Eval II pyrolysis.

Funding This study did not receive any specific funding.

Availability of data and material The authors confirm that the data supporting the findings of this study are available within the article.

\section{Declarations}

Conflict of interest On behalf of all the co-authors, the corresponding author states that there is no conflict of interest. 
Open Access This article is licensed under a Creative Commons Attribution 4.0 International License, which permits use, sharing, adaptation, distribution and reproduction in any medium or format, as long as you give appropriate credit to the original author(s) and the source, provide a link to the Creative Commons licence, and indicate if changes were made. The images or other third party material in this article are included in the article's Creative Commons licence, unless indicated otherwise in a credit line to the material. If material is not included in the article's Creative Commons licence and your intended use is not permitted by statutory regulation or exceeds the permitted use, you will need to obtain permission directly from the copyright holder. To view a copy of this licence, visit http://creativecommons.org/licenses/by/4.0/.

\section{References}

Adamolekun, O. J., Busch, B., Suess, M. P. and Hilgers, C. (2020). Diagenesis and Reservoir Quality of Sedimentary Rocks of the Eastern Dahomey Basin, Nigeria. In: Upstream Oil \& Gas Talks Climate and the Energy Transition. DGMK e.V., Hamburg, 2020, p. 243, ISSN 1433-9013, ISBN 978-3-947716 043

Adegoke OS, Coker SJL, Odunlami BE (1977) Geology of the bituminous sands of southern nigeria the nigerian mining, geological and metallurgical society 13th annual meeting. Proceed Abstr 14(2): $1-4$

Adegoke, O. S., Petters, S. W., Enu, E. I., Ako, B. D., AdegokeAnthony, C. W., Odebode, M. O. and Emofurieta, W. O. (1980). The bituminous sands of Ondo State in. Coker S. J. L, Ejedawe, J. E. (eds) Petroleum prospect of the Benin Basin Nigeria. J Min Geol. 23 (1) $27-43$

Adekeye, O. A., Akande, S. O, Adeoye, J. A. (2019). The assessment of potential source rocks of Maastrichtian Araromi formation in Araromi and Gbekebo wells Dahomey Basin, southwestern Nigeria Heliyon. 5501561

Ajayi, A. O. (1995). A Review of the Cretaceous Play in the Greater Niger Delta, Shell unpublished Internal Report XPMW 95010

Akande SO, Adekeye OA, Adeoye JA, Ojo OJ, Adeoye MO, Dominic W, Erdtmann BD (2018) Burial and thermal history of cretaceous sediments in the dahomey, anambra and gongola rift basins: implications for coal facies distribution and petroleum potential. FUOYE J Pure Appl Sci 3(1):309-325

Akinmosin A. A, Omosanya K. O., Ikhane P. R, Mosuro G. O. and Goodluck I. (2012). Characterization of a bitumen seepage in Eastern Dahomey Basin, SW, Nigeria. Adv Appl Sci Res, 2012. 3 (4) 2078-2089

Arnott, R. W. C, Hand, B. M. (1989). Bedforms, primary structures and grain fabrics in the presence of suspended sediment rain. J. Sedim. Petrol. 59, 1062-1069

Baniak GM, Kingsmith KG (2018) Sedimentological and stratigraphic characterization of cretaceous upper McMurray deposits in the southern Athabasca oil sands, Alberta, Canada. The Amer. Assoc. Petrol. Geolog. Bull. 102(2):309-332

Bankole SI, Shrank E, Erdtmann BD, Akande SO (2006) Palynostratigraphic age and paleoenvironments of the newly exposed section of the oshosun formation in the Sagamu quarry, Dahomey Basin, Southwestern, Nigeria. Niger. Assoc. Petrol. Explorat. Bull. 19(1):25-34

Boggs S (2009) Petrology of sedimentary rocks, 2nd edn. Cambridge University Press, Cambridge

Bolaji TA, Ndukwe OS, Oyebamiji AR, Ikegwuonu ON (2020) Palynological age control and paleoenvironments of the paleogene strata in Eastern Dahomey Basin. Southwestern Niger. Scient. Rep. 10:8991

Bouma AH, Berryhill HL, Brenner RL, Knebel HJ (1981) Continental shelf and epicontinental seaways. (eds Scholle, P. A., and Spearing, D.). The Amer. Assoc. Petrol. Geolog. Memoir 31:281-328

Burke, K. C. B., Dessauvagie, T. F. J, Whiteman, A. J., (1971). Nat. Physi Sci. 1971. 233 (38) 51-55

Bustin RM (1988) Sedimentology and characteristics of dispersed organic matter in Tertiary Niger Delta: the origin of source rocks in a deltaic environment. The Amer. Assoc. Petrol. Geolog. Bullet. 72:277-298

Bustin, R. M., Cameron, A, R., Grieve, D. A, Kalkreuth, W. D., (1985). Coal petrology; its principles, methods, and applications, $2 \mathrm{~d}$ edition. Geolog. Assoc. Canada Short Course Notes. 3,229

Çiftçi BN, Temel OR, Iztan HY (2010) Hydrocarbon occurrences in the western Anatolian (Aegean) grabens, Turkey: Is there a working petroleum system? The Amer. Assoc. Petrol. Geolog. Bullet 94(12): 1827-1857

Coker SJL (1982) Some aspects of the geology of the bituminous sands of parts of the Benin Basin. Niger. Min. Geosci. Soc. 19:121

Coker S. J. L, Adegoke O. S. and Odeyemi I. B. (2002). Tarsand Outcrop Belt, Dahomey Embayment. Field excursion guide to tar sand outcrops in Benin Basin. Nigerian Association of Petroleum Explorationists Mini-Conference, 24

Dembicki, H. (2016). Practical petroleum geochemistry for exploration and production. Elsevier. ISBN 978-0-12-803350-0 https://doi.org/10.1016/C2014-0-03244-3

Ehinola O. A, Oluwajana O. A. (2016). Conceptual basin models for Upper Senonian Araromi (marine) Formation in the Benin (Dahomey) Basin, southwestern Nigeria: preliminary insight into shale play prospectivity. Season of Rahaman Book of Abstract for students' symposium, 33-37

Ehinola OA, Sonibare OO, Falana AM, Jarvie D (2005) Organic geochemistry and biomarker evaluation of shale units of maastrichtian patti formation, Bida Basin, Nigeria. Niger. Assoc. Petrol. Explorat. Bullet. 10(1):78-88

Ehinola OA, Oluwajana A, Nwabueze CO (2012) Depositional environment, geophysical mapping and reserve estimation of Limestone deposit in Arimogija-Okeluse area, southwestern Nigeria. Res. J. Eng. Appl. Sci. 1(1):7-11

Elueze AA, Nton ME (2004) Organic geochemical appraisal of limestones and shales in part of eastern Dahomey basin, Southwestern Nigeria. J Min Geol 40(1):29-40

Enu EI, Adegoke OS (1988) Microfacies of shallow marine carbonates (Paleocene) in the eastern Dahomey Basin, southwestern Nigeria. J Min Geol 24(1):51-56

Famakinwa J, Ehinola OA, Yuhong L (2010) Organic geochemical evaluation of bituminous rocks and coals from Dahomey Basin. Niger. Assoc. Petrol. Explorat. Bullet. 22(2):15-27

Hafiz M, Hakhoo N, Bhat GM, Kanungo S, Thusu B, Craig J, Ahmed W (2020) Source potential and reservoir characterization of the Cambay Shale, Cambay Basin, India: implications for tight gas and tight oil resource development. The Amer. Assoc. Petrol. Geolog. Bullet. 104(8):1707-1749

Jarvie DM (2012) Shale resource systems for oil and gas: Part 2: Shaleoil resource systems. The Amer. Assoc. Petrol. Geolog. Memoir 97:89-119

Kaki, C., D'almeida, G. A. F., Yalo, N, Amelina, S. (2013). Geology and petroleum systems of the offshore benin basin. Oil Gas Sci. Technol Revue d'IFP Energies nouvelles, Institut Français du Pétrole. 2013, 68 (2) 363-381

Kavoosi MA, Lasemi Y, Sherkati S, Moussavi-Harami R (2009) Facies analysis and depositional sequences of the Upper Jurassic Mozduran Formation, a carbonate reservoir in the Kopet Dagh Basin, NE Iran. J Pet Geol 32(3):235-260

Klemme HD (1975) Geothermal gradients, heat flow, and hydrocarbon recovery. In: Fischer AG, Judson S (eds) Petroleum and Global

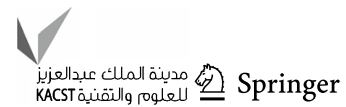


Tectonics. Princeton, NewJersey, Princeton University Press, pp 251-304

Kogbe, C. A. (1974). The Upper Cretaceous Abeokuta Formation of Southwestern Nigeria. Nigerian Field, 4. December 1974.

Lasemi, Y., Ghomashi, M., Amin-Rasouli, H, Kheradmand, A. (2008). The lower Triassic Sorkh Shale Formation of the Tabas Block, east-central Iran: Succession of a failed-rift Basin at the Paleotethys margin in Kavoosi et al. (eds) Facies analysis and depositional sequences of the Upper Jurassic Mozduran Formation, a carbonate reservoir in the Kopet Dagh Basin, NE Iran. J. Petrol. Geol, 32 (3) 235-260

MacGregor, D. S., Robinson J. and Spear G. (2003). Play fairways of the Gulf of Guinea transform margin in Arthur T. (eds) Petroleum Geology of Africa: New Themes and Developing Technologies Geological Society, London, Special Publications. 207. 131-150

Meilijson A, Finkelman-Torgeman E, Bialik OM, Boudinot FG, Steinberg J, Karcz ZK, Waldmann ND, Benjamini C, Vinegar H, Makovsky Y (2020) Significance to hydrocarbon exploration of terrestrial organic matter introduced into deep marine systems: insights from the lower Cretaceous in the Levant Basin. Mar Pet Geol. https://doi.org/10.1016/j.marpetgeo.2020.104671

MSMD, Ministry of solid minerals development (2006). Techn. Overv. Niger. Bitum. Belt Develop. Potent. March 6, 2006

Murat R. C. (1969). Stratigraphy and paleogeography of the Cretaceous and lower Paleogene-Neogene in southern Nigeria. Shell unpublished Internal Report

Nichols, G. (2009). Sedimentology and Stratigraphy, 2nd Edition. Wiley-Blackwell. 432

Nton ME, Ezeh FP, Elueze AA (2006) Aspects of source rock evaluation and diagenetic history of the Akinbo Shale, eastern Dahomey Basin, Southwestern Nigeria. Niger. Assoc. Petrol. Explorat. Bullet. 19(1):35-48

Nwachukwu JI, Ekweozor CM (1989) The origin of tar sands of SW, Nigeria. Niger. Assoc. Petrol. Explorat. Bullet. 4:82-94

Ogala JE, Kalaitzidis S, Christanis K, Omo-Irabor OO, Akinmosin A, Yusuf CU, Pasadakis N, Constantinopoulos M, Papaefthymiou H (2019) Geochemical and organic petrological study of bituminous sediments from Dahomey Basin, SW Nigeria. Mar Pet Geol 99:577-595

Ojo OJ, Akande SO (2006) Sedimentological and Palynological studies of the Patti formation, Southeastern Bida Basin, Nigeria:" implications for palaeoenvironment and palaeogeography. Niger. Assoc. Petrol. Explorat. Bullet. 19(1):61-77

Ojo OJ, Jimoh AY, Umelo JC, Akande SO (2020) Organic geochemical and palynological studies of the maastrichtian source rock intervals in Bida Basin, Nigeria. implications for hydrocarbon prospectivity. J. Petrol. Explor. Product. Technol. 10:3191-3206

Okeke KK, Umeji OP (2016) Palynostratigraphy, palynofacies, and palaeoenvironment of deposition of Selandian to Aquitanian sediments, southeastern Nigeria. J Afr Earth Sci 120:102-124

Okosun EA (1990) A review of the Cretaceous Stratigraphy of the Dahomey Embayment, West Africa. Cretac Res 11:17-27

Okosun EA, Alkali YB (2012) The paleocene- eocene foraminiferal biostratigraphy of Eastern Dahomey Basin, Southwestern Nigeria. Int J Sci Eng Res 3(11):1-14

Olabemiwo O, Esan AO, Adediran G, Bakare H (2016) The performance of Agbabu Natural Bitumen modified with polyphosphoric acid through fundamental and fourier transform infrared spectroscopic investigations. Case Stud Construct Mater. https:// doi.org/10.1016/j.cscm.2016.06.003

Olabode SO (2006) Siliciclastic slope deposits from the Cretaceous Abeokuta Group, Dahomey (Benin) Basin, southwestern Nigeria. J Afr Earth Sc 46:187-200

Olabode SO, Adekoya JA (2007) Seismic stratigraphy and development of Avon canyon in Benin (Dahomey) Basin, Southwestern Nigeria. J Afr Earth Sc 50:286-304

Oluwajana OA, Ehinola OA, Ofiwe CU, Akhayere E, Egunjobi K (2020) Depositional environment and diagenesis of Late Cretaceous-Early Paleogene carbonates on the Benin flank, Southwestern Nigeria. J. Afr. Earth Sci. 163:103762

Oluwajana, O. A., Adebambo, B. A., Olawuyi, G. T., Ewuji, J. O., Adejayan, B. A., Ayodele, O. D., Adeniran, P. M., Arabi, D. O, Adedokun, T. A. (2021). Paleoecologic implications of foraminiferal assemblages in the Upper Cretaceous-Paleogene strata, eastern Dahomey (Benin) Basin, southwestern Nigeria. Arab. J. Geosci. 14(9): 1-16 (2021). https://doi.org/10.1007/s12517-021-07038-x

Omatsola M. E, Adegoke O. S. (1981). Tectonic evolution and Cretaceous Stratigraphy of the Dahomey Basin in Adekeye et al (eds.): Hydrocarbon Potential Assessment of the Upper CretaceousLower Paleogene-Neogene Sequence in the Dahomey Basin Southwestern Nigeria. Niger. Assoc. Petrol. Explorat. Bullet, 19(1), 50-60

Peters KE (1986) Guideline for evaluating petroleum source rocks using programmed pyrolysis. The Amer. Assoc. Petrol. Geolog. Bullet. 70:318-328

Petters SW (1982) Central West African Cretaceous-Tertiary Benthic Foraminifera and Stratigraphy: Palaeontographica Abteilung 179:1-104

Petters, S. W. (1991). Regional Geology of Africa. Lecture Notes in Earth Sciences Series Vol. 40. xxi 722 pp. Berlin, Heidelberg, New York, London, Paris, Tokyo, Hong Kong: Springer-Verlag

Sachsenhofer RF, Popov SV, Akhmetiev MA, Bechtel A, Gratzer R, Groß D, Horsfield B, Rachetti A, Rupprecht B, Schaffar WBH, Zaporozhets NI (2017) The type section of the maikop group (Oligocene-lower Miocene) at the Belaya River (North Caucasus): Depositional environment and hydrocarbon potential. The Amer. Assoc. Petrol. Geolog. Bullet. 101(3):289-319

Sahay VK, Mude SN, Samant B (2015) Lithofacies and depositional environment of the ferruginous claystone member sediments of Naredi, Kutch, Gujarat. India India J. Appl Res 5(2):268-270

Specht RM, Brenner RL (1979) The genesis of bioclastic limestone lithosomes in upper Jurassic epicontinental mudstones, Southeastern Wyoming. J Sediment Petrol 49:1307-1322

Whiteman AJ (1982) Nigeria: its petroleum geology, resources, and potential. Grah. Trontman, London 2:167-382

Wolela A (2010) Sedimentation, organic maturity, and petroleum potential of the Oligocene-Miocene oil shale deposits, Yayu Basin, Southwestern Ethiopia. The Amer. Assoc. Petrol. Geolog. Bullet 94(5):643-663

Publisher's Note Springer Nature remains neutral with regard to jurisdictional claims in published maps and institutional affilitations. 